\title{
Transcriptome Profiling in Root Nodules and Arbuscular Mycorrhiza Identifies a Collection of Novel Genes Induced During Medicago truncatula Root Endosymbioses
}

\author{
Katja Manthey, ${ }^{1}$ Franziska Krajinski, ${ }^{2}$ Natalija Hohnjec, ${ }^{1,3}$ Christian Firnhaber, ${ }^{1}$ Alfred Pühler, ${ }^{1,4}$ \\ Andreas M. Perlick, ${ }^{1}$ and Helge Küster ${ }^{1,3}$ \\ ${ }^{1}$ Lehrstuhl für Genetik, Fakultät für Biologie, Universität Bielefeld, Postfach 100131, D-33501 Bielefeld, Germany; \\ ${ }^{2}$ Lehrgebiet Molekulargenetik, Universität Hannover, Herrenhäuser Straße 2, D-30419 Hannover, Germany; ${ }^{3}$ International \\ NRW Graduate School in Bioinformatics and Genome Research, Center for Biotechnology (CeBiTec), Bielefeld University, \\ D-33594 Bielefeld Germany; ${ }^{4}$ Institute of Genome Research, Center for Biotechnology (CeBiTec), Bielefeld University, D- \\ 33594 Bielefeld, Germany
}

Submitted 22 January 2004. Accepted 18 June 2004.

\begin{abstract}
Transcriptome profiling based on cDNA array hybridizations and in silico screening was used to identify Medicago truncatula genes induced in both root nodules and arbuscular mycorrhiza (AM). By array hybridizations, we detected several hundred genes that were upregulated in the root nodule and the AM symbiosis, respectively, with a total of 75 genes being induced during both interactions. The second approach based on in silico data mining yielded several hundred additional candidate genes with a predicted symbiosisenhanced expression. A subset of the genes identified by either expression profiling tool was subjected to quantitative real-time reverse-transcription polymerase chain reaction for a verification of their symbiosis-induced expression. That way, induction in root nodules and AM was confirmed for 26 genes, most of them being reported as symbiosis-induced for the first time. In addition to delivering a number of novel symbiosis-induced genes, our approach identified several genes that were induced in only one of the two root endosymbioses. The spatial expression patterns of two symbiosisinduced genes encoding an annexin and a $\beta$-tubulin were characterized in transgenic roots using promoter-reporter gene fusions.
\end{abstract}

Plant roots have the capacity to form different symbioses resulting in an improved acquisition of limiting macro- and micronutrients from the soil. The two most commonly studied symbiotic interactions are the arbuscular mycorrhiza (AM) formed between the majority of land plant species and fungi of the phylum Glomeromycota (Schüssler et al. 2001) and the root nodule symbiosis between legumes and bacteria of the family Rhizobiaceae. Whereas the microsymbiont in both associations benefits by acquiring photoassimilates from the plant, the macrosymbiont obtains fixed nitrogen in case of root nodules (Brewin 1991; Crespi and Galvez 2000) and mainly phosphate in case of AM (Harrison 1999; Strack et al. 2003). The latter interaction is accompanied by further beneficial effects

Corresponding author: Helge Küster, Telephone: +49 521106 4819; Fax: +49 521106 5626; E-mail: Helge.Kuester@ Genetik.Uni-Bielefeld.DE

* The $\boldsymbol{e}$-Xtra logo stands for "electronic extra" and indicates the HTML abstract available on-line contains four supplemental tables not included in the print edition. such as a greater resistance against abiotic stress (Augé 2001; Subramanian et al. 1995) and a significant degree of bioprotection against pathogen attacks (Cordier et al. 1996; Newsham et al. 1995; Slezack et al. 2000).

Legumes, with the exception of lupin, have the unique ability to establish both symbioses; therefore, they became general model systems for investigating mutualistic plant-microbe interactions. In recent years, it has emerged that, despite obvious differences between both associations, there is a certain overlap in the activation of gene expression and in signal transduction pathways. One of the first evidences for these common steps was the existence of plant mutants affected in both root nodule and AM development (Bradbury et al. 1991; Duc et al. 1989). Recently, several genetic determinants controlling early steps of signal recognition and the subsequent signal transduction pathway that leads to an induction of symbiotic responses were isolated by positional cloning (Ané et al. 2004; Endre et al. 2002; Levy et al. 2004; Stracke et al. 2002). In addition, a number of plant genes identified by differential or subtractive hybridizations were shown to be specifically activated in both symbioses (e.g., VfLb29, MsENOD2, MsENOD40, PsENOD5, PsENOD12A, MtENOD11, and MtENOD12) (Albrecht et al. 1998; Frühling et al. 1997; Journet et al. 2001; van Rhijn et al. 1997).

It can be anticipated that a more global nontargeted approach (e.g., by means of expressed sequence tag [EST] sequencing or the application of DNA arrays to monitor gene expression) would reveal a larger number of candidate genes being connected to root endosymbioses that were not identified on the basis of either mutant analysis or differential hybridzation approaches. A high-throughput transciptomics approach prerequisites a certain amount of sequence data. Over the past years, several EST sequencing projects were performed (VandenBosch and Stacey 2003), primarily in the two model legumes Medicago truncatula (Barker et al. 1990) and Lotus japonicus (Handberg and Stougaard 1992). In case of M. truncatula, the resulting EST sequences were incorporated into three major databases: the TIGR Medicago truncatula Gene Index (MtGI) (Quackenbush et al. 2000), the MtDB (Lamblin et al. 2003), and the Medicago EST navigation system (MENS) (Journet et al. 2002) database. The current release of the TIGR MtGI contains over 190,000 ESTs from more than 40 cDNA libraries that represent a range of tissues and conditions. In the databases 
mentioned, EST sequences are assembled into clusters to form consensus sequences representing putative distinct transcript sequences. Based on the EST distribution in the cluster sequences, all three databases can be used for in silico data mining (electronic Northerns) targeted at identifying genes with a particular expression pattern. For example, Fedorova and associates (2002) used the MtGI to predict nodule-specific genes and Journet and associates (2002) identified genes that were proposed to be up- or downregulated in the root nodule, AM symbiosis, or both by performing in silico comparisons on the basis of the MENS database.

Apart from being a prerequisite for electronic Northern approaches, EST clusters can be used to generate arrays for the large-scale analysis of differential gene expression after identification of cluster-representative cDNAs. Transcript profiling in legumes based on arrays was reported for $L$. japonicus (Colebatch et al. 2002; Endo et al. 2002), Glycine max (Maguire et al. 2002), M. truncatula (Liu et al. 2003) and Lupinus albus (Uhde-Stone et al. 2003). Most relevant for the study of root endosymbioses were the experiments by Colebatch and associates (2002) and Liu and associates (2003), who identified more than 50 novel nodule-induced genes and more than 60 novel AM-induced genes, respectively, on the basis of macroarrays constructed from polymerase chain reaction (PCR)-amplified cDNAs.

Recently, we reported the construction of cDNA-based macro- and microarrays (Küster et al. 2004) that represent 5,648 EST clusters from $M$. truncatula young root nodules, AM, and noninfected roots (Journet et al. 2002). Because these arrays cover a substantial part of the root endosymbiotic program, they were designated Mt6k-RIT (M. truncatula $6 \mathrm{k}$ root interaction transcriptome). Two pilot expression profiling experiments demonstrated the usability of these tools for the detection of genes differentially expressed during nodulation and AM formation (Küster et al. 2004). Using experimental expression profiling based on Mt6k-RIT arrays complemented by in silico data mining of the MENS database (Journet et al. 2002), we here describe the identification of $M$. truncatula genes that are activated in root nodules as well as AM. Selected genes showing a symbiosis-enhanced expression were validated by quantitative realtime RT-PCR experiments. Based on these data, we present a collection of $M$. truncatula genes that are induced in both endosymbioses and, thus, probably encode proteins relevant during either plant-microbe interaction. By studying the expression of promoter-gus fusions in transgenic hairy roots, we were able to localize the promoter activity of two symbiosis-induced genes in root nodules and AM.

\section{RESULTS}

Array-based expression profiling in root nodules and AM to identify symbiosis-related $M$. truncatula genes.

We reported recently on Mt6k-RIT macro- and microarrays consisting of 5,648 PCR probes that represent genes expressed in symbiotic and noninfected roots (Küster et al. 2004). In this study, these arrays were used to compare gene expression in root nodules and AM relative to noninfected roots in order to identify those $M$. truncatula genes that are differentially expressed in both symbioses.

Total RNA was extracted from root nodules, AM-infected roots, and the corresponding noninoculated control roots and used to synthesize labeled hybridization targets. Two technical replicates for root nodules versus noninfected roots as well as $\mathrm{AM}$ versus nonmycorrhized roots were performed for either tool. In order to improve signal intensity, ${ }^{33} \mathrm{P}$-labeled cDNA targets amplified by PCR were used for hybridization on Mt6k-RIT macroarrays. In case of Mt6k-RIT microarrays, we applied Cy-labeled cDNA targets amplified by PCR as well as Cy-labeled cDNA targets being reverse-transcribed in two separate hybridization experiments.

Image data from array hybridizations were processed as described in the Material and Methods section. Signal intensities were used to calculate $\mathrm{M}$ values ( $\log _{2}$ of expression ratios) and $\mathrm{A}$ values ( $\log _{2}$ of average signal intensities) after lowess normalization with the EMMA 1.0 array analysis software (Dondrup et al. 2003). In the case of macroarrays, data obtained from two replicate membranes were combined. In contrast, the microarray data were analyzed separately due to the use of different methods for target generation. A $t$ statistic was applied to test the significance of expression ratios observed. All probes with a confidence value of $P \leq 0.075$ were considered for the subsequent identification of differentially expressed genes. In the case of macroarrays, an additional A value threshold was defined in every single experiment according to the A values of empty control spots. To illustrate the range of signal intensities obtained, ratio plots for macro- and microarray experiments are shown in Figure 1.

In general, expression ratios greater than twofold are considered to be of biological significance. In an initial control experiment with separately generated PCR-amplified targets from the same first-strand cDNA template hybridized to the same macroarray filter, $99.9 \%$ of the genes showed differences in signal intensities that did not exceed a 1.3-fold regulation ( $\mathrm{M}$ value $\leq 0.4$ or $\geq-0.4$, data not shown). Based on this control and considering the fact that PCR amplification leads to a quenching of expression ratios, we decided to accept genes as being differentially regulated in case of $M$ values $\geq 0.7$ or $\leq-0.7$ ( $\geq 1.6$-fold and $\leq 0.6$-fold, respectively). The same threshold values were applied in experiments with reverse-transcribed cDNA targets. We intentionally used less stringent criteria to obtain an enhanced overlap between the two symbioses, accepting the possibility of a certain proportion of false positives, because selected genes were subjected to a verification by reverse-transcription (RT)-PCR.

Based on these criteria, we identified more than 900 probes that were upregulated in root nodules compared with control roots in at least one of the hybridization experiments performed. An equal number of probes was downregulated in root nodules. Within the 50 most highly induced genes, we were able to detect a large number of typical nodule-specific or noduleenhanced genes such as ENOD11 (Journet et al. 2001), carbonic anhydrase (Coba de la Pena et al. 1997), PEP carboxylase (Pathirana et al. 1992), and a gene encoding a leghemoglobin (MtGI TC76986). Several genes belong to the group of nodule-specific MtN genes identified by Gamas and associates (1996). These results demonstrate the principal validity of our array analyses.

Concerning roots infected with Glomus intraradices, more than 600 probes were found to be upregulated, whereas the transcript levels of almost 500 probes were more abundant in noninfected roots. Again, we were able to identify a number of genes previously characterized as AM-induced, such as the phosphate transporter MtPT4 (Harrison et al. 2002), a serine carboxypeptidase (Liu et al. 2003), a nodulin 26-like membrane intrinsic protein (Brechenmacher et al. 2004), a lectin precursor, and a syringomycin biosynthesis-like protein and glutathione S-transferase (Wulf et al. 2003).

Surprisingly, only 77 probes representing 75 different genes were induced in both symbioses, and only 106 probes exhibited a root-enhanced expression. The complete set of genes activated in both symbioses is displayed in Table 1. A significant proportion of the encoded proteins showed no homology to proteins described so far or was homologous only to proteins of unknown function (Table 1). Another dominant group com- 
prised genes involved in primary metabolism, whereas only a few symbiosis-upregulated genes are related to the build-up of the cell wall and the cytoskeleton or might be connected to vesicular trafficking, protein secretion, and protein sorting. The remainder of the genes was involved in different cellular functions, such as membrane transport, gene expression and RNA metabolism, signal transduction, and post-translational regulation, as well as defense reactions and cell rescue.

From the 75 genes identified as being symbiosis-induced on the basis of our array results, 17 were chosen for verification studies by quantitative real-time RT-PCR (Table 1). We included some of the highly induced genes as well as some genes that exhibit an expression ratio just above the chosen cutoff to justify the less stringent criteria used for the selection of candidates.

\section{Using in silico expression profiling}

to identify genes induced in both root nodules and AM.

Journet and associates (2002) used an in silico screening tool to predict genes up- and downregulated during nodule and AM symbiosis using a likelihood ratio $\mathrm{R}$ that allows the evaluation of the statistical significance of the observed differences in EST distribution within clusters. The proportion of estimated true positives declines markedly at lower $\mathrm{R}$ values; therefore, the authors used an $\mathrm{R}$ value of 4 for their analyses. Although a large number of candidate genes for the early root nodule and the AM symbiotic program were identified, Journet and associates (2002) described only 19 clusters as being upregulated in both the mycorrhiza library MtBC and in root nodule libraries, respectively, based on a comparison with non-infected roots.

We found no overlap between the 19 clusters predicted to be symbiosis-upregulated by in silico analyses $(R \geq 4)$ and the
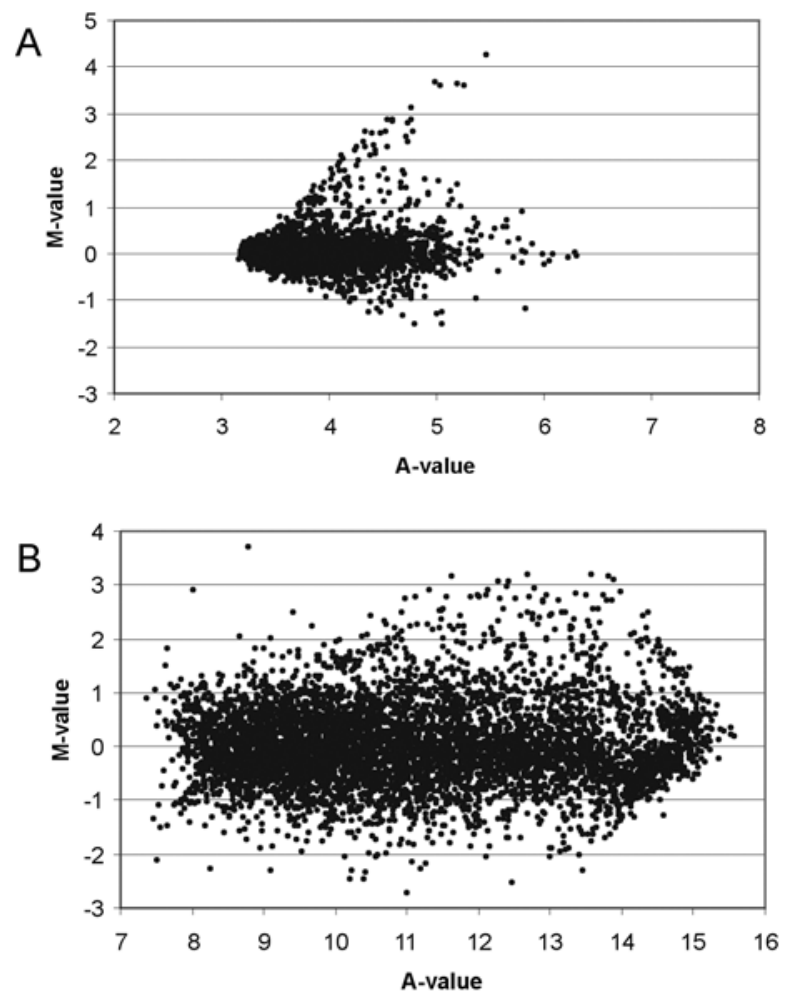

genes identified to be induced in both symbioses by the array hybridizations presented above; therefore, we performed an in silico screening based on a much less stringent $R$ value $(R \geq$ 1.5). In addition, we also incorporated more libraries and library groups than Journet and associates (2002) in our analyses in order to increase the number of genes with a putative symbiosis-enhanced expression pattern.

When comparing the two mycorrhiza libraries, MHAM and MtBC, as well as the classes mycorrhizae, young nodules, mature nodules, and Rhizobium roots, to the six pooled libraries for noninoculated roots (metaclass roots), 439 clusters were predicted to be upregulated in at least one class representing the nodule symbiosis and, simultaneously, in at least one library or class representing the AM symbiosis ( $\mathrm{R} \geq 1.5$, data not shown). Among these clusters, nine genes were already identified by the array hybridizations presented above. A subset of 53 clusters were selected for further analysis in quantitative real-time RT-PCR experiments, including six clusters that already were identified as symbiosis-induced on the basis of our array data. In our selection, clusters predicted to be upregulated at high $\mathrm{R}$ values were preferred, but we also included clusters with $\mathrm{R}$ values just above the threshold of 1.5. Of the 53 selected clusters, 7 matched the $\mathrm{R} \geq 4$ criterion used by Journet and associates (2002) and, thus, already were predicted as candidate genes for the common symbiotic program of $M$. truncatula roots.

\section{Using quantitative real-time RT-PCR to validate the symbiosis-induced expression of selected candidate genes.}

We performed quantitative real-time RT-PCR to verify the experimental and, in particular, the in silico expression pat-
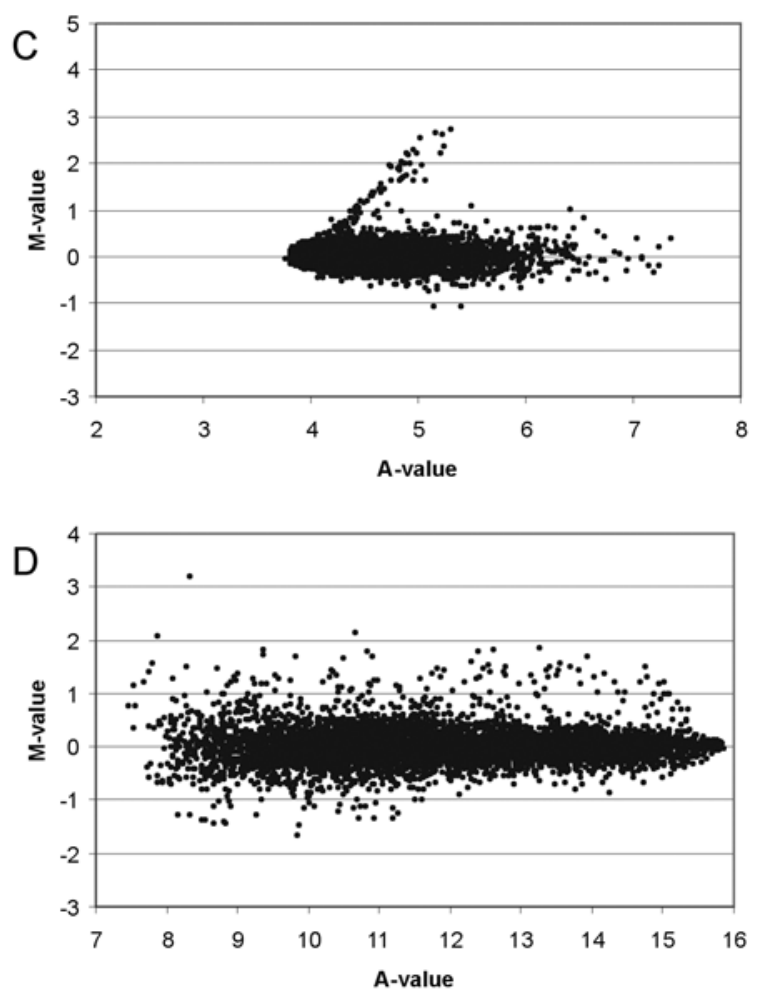

Fig. 1. Ratioplots obtained in macro- and microarray hybridization experiments designed to identify genes differentially expressed during the root nodule and the arbuscular mycorrhiza (AM) symbiosis in Medicago truncatula. M values denote $\log _{2}$ of expression ratios and $\mathrm{A}$ values indicate the $\log _{2}$ of average signal inensities. All spots with detectable signal intensities are displayed. A, Ratio plot of a macroarray experiment based on two sets of replicate membranes consecutively hybridized with polymerase chain reaction (PCR)-amplified cDNA targets from root nodules and control roots. B, Ratio plot of a microarray hybridization experiment with PCR-amplified cDNA targets from nodules and control roots. C, Ratio plot of a macroarray experiment based on two sets of replicate membranes consecutively hybridized with PCR-amplified cDNA targets from roots mycorrhized with Glomus intraradices and control roots. D, Ratio plot of a microarray hybridization experiment with PCR-amplified cDNA targets from AM and control roots. 
terns for a total of 64 putative symbiosis-upregulated genes, 17 being derived from array hybridizations and 47 being predicted exclusively by in silico studies. Primer pairs were designed for each gene and tested for specificity by Blast comparisons against the TIGR MtGI and the MENS database. The expression level of the housekeeping gene MtEF1- $\alpha$ encoding an elongation factor 1- $\alpha$ (Wulf et al. 2003) was used to normalize gene expression. Whereas the phosphate transporter MtPT4 (Harrison et al. 2002) was chosen as a marker for mycorrhization efficiency, two nodule-specific genes encoding MtNod25 (MtGI TC85750) and MtENOD18 (MtGI TC77759) were used to exclude contaminations of AM and noninfected roots with root nodules (data not shown).

Two independently grown samples of root nodules, AM, and the corresponding noninfected control roots were used as biological replicates to extract total RNA for one-step real-time RT-PCR, with one replicate corresponding to the RNA used for array hybridizations.
The specificity of the PCR-products obtained was confirmed by performing a heat dissociation protocol following the final cycle of the PCR and, subsequently, by agarose gel electrophoresis (data not shown). We tested each gene in at least two technical replicates and performed a Student's $t$ test to calculate the significance of observed ratios between the means of expression levels in arbuscular mycorrhizal roots and root nodules compared with the corresponding control tissues. Only those genes were regarded as significantly induced that exhibited an expression ratio larger than twofold with a $P$ value $\leq 0.05$ in both biological replicates.

In 12 of 17 cases, the quantitative real-time RT-PCR data supported the symbiosis-enhanced expression pattern determined by our array experiments (Table 2), whereas four candidate genes (MtC30105, MtC50926, MtC45259, and MtC30081) were found to be upregulated only in nodules and one gene (MtC91068) was induced in neither nodules nor AM. The nodule versus root expression ratios determined by RT-PCR analy-

Table 1. List of 77 probes that were identified as symbiosis-upregulated by cDNA array hybridizations ${ }^{\mathrm{a}}$

\begin{tabular}{|c|c|c|c|}
\hline Cluster & Annotation & $\begin{array}{l}\text { Maximum induction } \\
\text { in nodules }\end{array}$ & $\begin{array}{l}\text { Maximum induction } \\
\text { in mycorrhiza }\end{array}$ \\
\hline \multicolumn{4}{|l|}{ I. Cell wall } \\
\hline BE999060 ${ }^{\mathrm{b}}$ & $\mathrm{M}+\mathrm{N} 8$ & 2.22 & 1.72 \\
\hline \multicolumn{4}{|l|}{ II. Cytoskeleton } \\
\hline $\mathrm{MtC} 30198^{\mathrm{b}, \mathrm{c}}$ & Tubulin $\beta$ chain & 3.37 & 2.45 \\
\hline 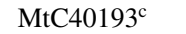 & Myosin-like protein & 1.63 & 1.95 \\
\hline \multicolumn{4}{|c|}{ III. Membrane transport } \\
\hline $\mathrm{MtC} 10430^{\mathrm{b}, \mathrm{c}, \mathrm{d}}$ & Nodulin 26-like protein & 48.62 & 31.46 \\
\hline BG582879 & Nodulin 26-like protein & 11.07 & 7.19 \\
\hline AJ311233 & Nodulin 26-like protein & 6.60 & 110.57 \\
\hline $\mathrm{MtC} 10090.1^{\mathrm{c}}$ & Glucose-6-phosphate/phosphate translocator precursor & 2.14 & 1.83 \\
\hline BG583224 ${ }^{\mathrm{b}}$ & Nodulin 26-like protein & 5.85 & 1.86 \\
\hline \multicolumn{4}{|c|}{ IV. Vesicular trafficking, secretion, and protein sorting } \\
\hline MtC00195,d & DNAJ domain containing protein & 2.09 & 5.76 \\
\hline \multicolumn{4}{|c|}{ V. Primary metabolism } \\
\hline $\mathrm{MtC} 00728^{\mathrm{c}}$ & Forminotransferase-cyclodeaminase & 2.45 & 1.69 \\
\hline $\mathrm{MtC} 10279^{\mathrm{b}, \mathrm{d}}$ & Heme oxygenase & 2.00 & 1.68 \\
\hline $\mathrm{MtC} 10290^{\mathrm{b}, \mathrm{c}}$ & Mtha1 plasma membrane ATPase & 4.01 & 6.67 \\
\hline MtC20123 $3^{\mathrm{b}, \mathrm{d}}$ & $\beta$-Ketoacyl-ACP synthase & 1.66 & 4.85 \\
\hline $\mathrm{MtC} 20314^{\mathrm{c}}$ & Aspartate aminotransferase & 3.63 & 2.15 \\
\hline $\mathrm{MtC} 30105^{\mathrm{b}, \mathrm{c}}$ & $\beta$-Amylase & 2.68 & 2.03 \\
\hline $\mathrm{MtC} 45154^{\mathrm{c}}$ & $\alpha$-Mannosidase & 2.02 & 2.40 \\
\hline $\mathrm{MtC} 45203.1^{\mathrm{c}}$ & CTP synthase & 1.70 & 1.98 \\
\hline MtC45259 b,c,d & Riboflavin biosynthesis protein ribA $\mathrm{e}^{\mathrm{e}}$ & 2.45 & 2.49 \\
\hline MtC50926 & Apsartate aminotransferase & 1.76 & 3.20 \\
\hline $\mathrm{MtC} 90381^{\mathrm{c}}$ & Sugar epimerase family & 1.74 & 1.64 \\
\hline $\mathrm{MtC} 90507^{\mathrm{c}}$ & Nicotinate-nucleotide phosphorylase & 2.01 & 1.69 \\
\hline BG581412 ${ }^{\mathrm{b}}$ & ENOD8 & 13.60 & 1.70 \\
\hline MsAGPase $^{\mathrm{f}}$ & AGP-glucose phosphorylase & 2.78 & 2.00 \\
\hline $\mathrm{MsCA}^{\mathrm{g}}$ & Carbonic anhydrase & 11.36 & 2.15 \\
\hline \multicolumn{4}{|c|}{ VI. Secondary metabolism and hormone metabolism } \\
\hline $\mathrm{MtC} 30070^{\mathrm{c}}$ & UDP-glycose:flavonoid glycosyltransferase & 2.69 & 1.75 \\
\hline $\mathrm{MtC} 40164^{\mathrm{c}}$ & Short chain alcohol dehydrogenase (tropinone reductase-like) & 1.89 & 1.71 \\
\hline $\mathrm{MtC} 45591^{\mathrm{c}}$ & Isoflavone-O-methyltransferase & 2.96 & 1.72 \\
\hline $\mathrm{MtC} 90268^{\mathrm{c}}$ & Glucosyltransferase & 1.65 & 1.76 \\
\hline \multicolumn{4}{|c|}{ VIII. Gene expression and RNA metabolism } \\
\hline $\mathrm{MtC} 00467^{\mathrm{b}, \mathrm{c}}$ & Transcriptional adaptor zinc finger containing protein & 2.21 & 2.99 \\
\hline $\mathrm{MtC} 91009^{\mathrm{c}}$ & Homeodomain protein & 3.15 & 1.78 \\
\hline $\mathrm{MtC} 91222^{\mathrm{c}}$ & YABBY protein transcription factor ${ }^{\mathrm{e}}$ & 1.79 & 26.70 \\
\hline \multirow[t]{2}{*}{$\mathrm{MtC} 92147.1^{\mathrm{c}}$} & TCP family transcription factor ${ }^{\mathrm{e}}$ & 2.46 & 1.78 \\
\hline & & \multicolumn{2}{|r|}{ (continued on next page) } \\
\hline
\end{tabular}

a The induction factor indicated is the maximum expression ratio measured in any of the macro- or microarray experiments performed. Probes with the identifiers MtC10430, BG582879, and AJ311233 correspond to the same gene. Unless otherwise noted, MtC cluster IDs, annotations, and the classification into functional categories are taken from the current release of the MENS database.

${ }^{\mathrm{b}}$ The gene was chosen for verification studies by quantitative real-time reverse-transcription polymerase chain reaction.

${ }^{\mathrm{c}}$ Probe derived from Journet and associates (2002)

$\mathrm{d}$ The gene also was identified as being upregulated in both symbioses by in silico data mining.

${ }^{\mathrm{e}}$ Annotations were updated according to current homologies in the GenBank database.

${ }^{\mathrm{f}}$ Probe derived from clone collection, Bielefeld University.

${ }^{\mathrm{g}}$ Probe derived from Coba de la Pena and associates (1997).

${ }^{\mathrm{h}}$ Probe derived from Gamas and associates (1996).

${ }^{i}$ Probe derived from D. v. Tuinen, INRA, Dijon. 
sis were higher than the ratios determined by our array hybridization; in some cases, with several thousand-fold difference. With only a few exceptions, we found a similar tendency for the AM versus root expression ratios, albeit not to the same extent (Tables 1 and 2). These results reflect the fact that real-time RTPCR is a more sensitive technique than transcript profiling using arrays and is not likely to be affected by related transcripts that cause problems of cross-hybridization, at least with gene-specific primers. These findings are in agreement with the results of Colebatch and associates (2000) although, here, less-pronounced differences in expression ratios were observed.

Concerning candidate genes identified through in silico studies, an induction in both symbioses was demonstrated for 18 of 53 candidate genes, including four genes also identified by array hybridization (Table 2). From the remainder, a significant proportion was upregulated in only one symbiosis. That way, 10 genes were found to be induced in root nodules, including 2 that we also present in the set of candidate genes derived from the array experiments, whereas 5 genes were induced in AM (Table 2). A total of 20 genes were not significantly induced, in contrast to the prediction from in silico data. Thus, and as expected due to the intentionally low $\mathrm{R}$ value used, the proportion of true positives among the candidate genes from the in silico predictions was lower than among the genes identified by array hybridization.

In conclusion, our verification studies by RT-PCR yielded a total of $26 \mathrm{M}$. truncatula genes induced in both the root nodule and the AM symbiosis. These genes correspond to a range of functional classes (Table 2), with the most prominent classes being unknown function (five genes) as well as defense and cell rescue (four genes). Interestingly, three genes involved in gene expression and RNA metabolism were identified, among those two genes encoding putative transcriptional regulators of the symbiotic program.

Table 1. (continued from preceding page)

\begin{tabular}{|c|c|c|c|}
\hline Cluster & Annotation & $\begin{array}{c}\text { Maximum induction } \\
\text { in nodules }\end{array}$ & $\begin{array}{l}\text { Maximum induction } \\
\text { in mycorrhiza }\end{array}$ \\
\hline \multicolumn{4}{|c|}{ IX. Protein synthesis and processing } \\
\hline $\mathrm{MtC} 30415^{\mathrm{c}}$ & Signal peptidase & 3.80 & 2.27 \\
\hline $\mathrm{MtC} 90330^{\mathrm{c}}$ & Cysteine proteinase & 2.29 & 1.93 \\
\hline $\mathrm{MtC} 91471^{\mathrm{b}, c, d}$ & Cysteine proteinase & 10.64 & 204.32 \\
\hline MtC92056 ${ }^{\mathrm{c}}$ & Cysteine proteinase & 4.70 & 2.70 \\
\hline \multicolumn{4}{|c|}{ X. Signal transduction and posttranslational regulation } \\
\hline $\mathrm{MtC} 10763^{\mathrm{c}}$ & Annexin & 3.12 & 2.52 \\
\hline $\mathrm{MtC} 20129^{\mathrm{b}, \mathrm{c}}$ & Annexin & 4.84 & 4.61 \\
\hline MtC40217 & DNAJ-like protein & 1.84 & 2.11 \\
\hline $\mathrm{MtC} 50655^{\mathrm{c}}$ & Caltractin ${ }^{\mathrm{e}}$ & 1.86 & 2.46 \\
\hline \multicolumn{4}{|c|}{ XII. Miscellaneous } \\
\hline $\mathrm{MtC} 10199^{\mathrm{c}}$ & Late embryogenesis abundant protein & 1.76 & 2.39 \\
\hline MtC91313 & ENBP1 protein DNA-binding zinc finger protein-like & 1.76 & 1.77 \\
\hline $\mathrm{MtC} 93025^{\mathrm{c}}$ & Zinc finger protein & 1.76 & 2.45 \\
\hline \multicolumn{4}{|c|}{ XII.A. Defense and cell rescue } \\
\hline $\mathrm{MtC} 10348.1^{\mathrm{b}, \mathrm{c}, \mathrm{d}}$ & Glyoxalase I family protein ${ }^{\mathrm{e}}$ & 2.52 & 2.77 \\
\hline $\mathrm{MtC} 50782.1^{\mathrm{c}}$ & MLO-like protein & 1.68 & 1.90 \\
\hline MtC90364 & Resistance protein (nucleotide-binding leucine-rich repeat) & 1.83 & 2.09 \\
\hline MtC91398 & Antifungal protein-like ${ }^{\mathrm{e}}$ & 1.73 & 10.09 \\
\hline $\mathrm{MtC} 93362^{\mathrm{b}, \mathrm{c}, \mathrm{d}}$ & Wound-induced protein & 5.17 & 2.80 \\
\hline \multicolumn{4}{|c|}{ XII.B. Abiotic stimuli and development } \\
\hline $\mathrm{MtC} 00045^{\mathrm{c}}$ & Auxin-downregulated ADR6-like protein & 1.69 & 1.93 \\
\hline $\mathrm{MtC} 00667^{\mathrm{c}}$ & Aluminium-induced auxin-repressed protein & 1.76 & 2.44 \\
\hline $\mathrm{MtC} 00716.1^{\mathrm{c}}$ & Zwille/pinhead/argonaute protein & 1.80 & 1.75 \\
\hline $\mathrm{MtC} 10128^{\mathrm{c}}$ & Aluminium-induced auxin-repressed protein & 1.86 & 1.66 \\
\hline $\mathrm{MtC} 30584^{\mathrm{c}}$ & Small auxin-induced protein & 1.75 & 1.74 \\
\hline $\mathrm{MtC} 91534.2^{\mathrm{c}}$ & Wound-responsive protein & 2.36 & 2.80 \\
\hline \multicolumn{4}{|c|}{ XII.C. Unknown function } \\
\hline${\mathrm{MtC} 00603^{\mathrm{c}}}$ & BURP domain containing protein & 1.79 & 19.26 \\
\hline $\mathrm{MtC} 00658^{\mathrm{c}}$ & Hypothetical protein & 1.95 & 38.94 \\
\hline $\mathrm{MtC} 10415^{\mathrm{c}}$ & Hypothetical protein & 1.78 & 1.82 \\
\hline MtC30081 & Hypothetical protein & 2.50 & 1.77 \\
\hline $\mathrm{MtC} 30324^{\mathrm{c}}$ & Negatively light-regulated protein-like protein & 2.23 & 1.82 \\
\hline $\mathrm{MtC} 00125.1^{\mathrm{c}}$ & Hypothetical protein & 2.06 & 2.13 \\
\hline MtC90241 & Integral membrane protein & 3.06 & 1.69 \\
\hline MtC90830 & Hypothetical protein ${ }^{\mathrm{e}}$ & 2.24 & 2.04 \\
\hline MtC91068 b,c & Hypothetical protein & 2.65 & 1.70 \\
\hline $\mathrm{MtC} 91080^{\mathrm{c}}$ & Hypothetical protein & 1.90 & 1.91 \\
\hline MtC91127 & Hypothetical protein ${ }^{\mathrm{e}}$ & 2.12 & 1.70 \\
\hline JVCPG- $48^{\mathrm{h}}$ & MtN21 & 5.83 & 1.66 \\
\hline MtGmLS- $88^{\mathrm{i}}$ & Hypothetical protein & 1.88 & 46.64 \\
\hline \multicolumn{4}{|c|}{ XIII. No homology } \\
\hline $\mathrm{MtC} 00483^{\mathrm{c}}$ & $\ldots$ & 1.84 & 1.72 \\
\hline $\mathrm{MtC} 30515^{\mathrm{c}}$ & $\ldots$ & 3.98 & 2.53 \\
\hline $\mathrm{MtC} 90859^{\mathrm{c}}$ & $\ldots$ & 2.58 & 1.77 \\
\hline $\mathrm{MtC} 90926^{\mathrm{c}}$ & $\ldots$ & 2.16 & 1.76 \\
\hline $\mathrm{MtC} 91682^{\mathrm{c}}$ & $\ldots$ & 1.72 & 3.03 \\
\hline MtC91708 ${ }^{\mathrm{c}}$ & $\ldots$ & 2.09 & 1.68 \\
\hline${\mathrm{MtC} 92143^{\mathrm{c}}}$ & $\ldots$ & 1.87 & 3.18 \\
\hline $\mathrm{MtC} 92162^{\mathrm{b}, \mathrm{c}}$ & $\ldots{ }^{e}$ & 4.74 & 16.58 \\
\hline $\mathrm{MtC} 92236^{\mathrm{c}}$ & $\ldots$ & 1.64 & 1.93 \\
\hline $\mathrm{MtC} 92239^{\mathrm{c}}$ & $\ldots$ & 2.93 & 1.86 \\
\hline
\end{tabular}


Promoter activity of the annexin gene MtAnn2 and the $\beta$-tubulin gene $M t T u b b 1$ in root nodules and $A M$.

The two symbiosis-induced genes represented by clusters MtC20129 and MtC30198 were selected for an analysis of their spatial expression pattern. MtC20129 is predicted to encode a protein that shares $75 \%$ identity with the annexin MtAnn1 (de Carvalho-Niebel et al. 1998). Thus, the corre- sponding gene was designated MtAnn2. The MtC30198 cluster represents the MtTubbl gene, because its deduced amino acid sequence shares over $90 \%$ identity with tubulin $\beta$ chain proteins of various plants. A 1,747-bp MtAnn2 promoter fragment (pMtAnn2) and a 1,727-bp MtTubbl promoter fragment ( $\mathrm{pMtTubbl)}$ were fused to the gusAint reporter gene. Reporter gene expression was studied in transgenic hairy roots either

Table 2. List of clusters with an enhanced expression in root nodules and arbuscular mycorrhiza (AM) on the basis of quantitative real-time reversetranscription polymerase chain reaction experiments ${ }^{\mathrm{a}}$

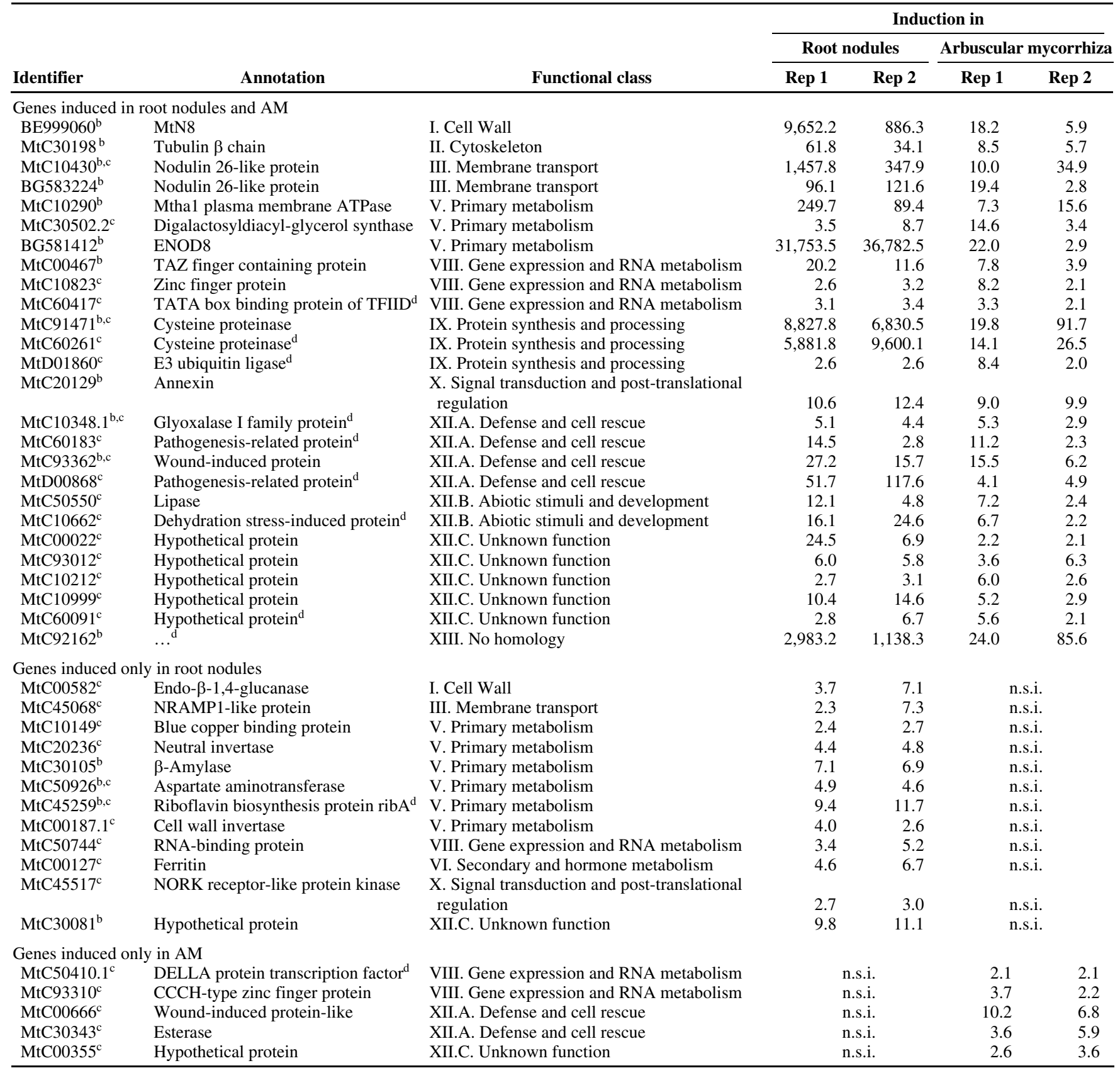

${ }^{\mathrm{a}}$ For each biological replicate, expression ratios were based on the data from at least two technical replicates. Only expression ratios for genes with a differential expression greater than twofold and a confidence value of $P \leq 0.05$ are shown. Only genes that match these criteria in both biological replicates are regarded as significantly induced. In all, 26 genes were found to be upregulated in both symbioses, 13 genes were induced only in root nodules, and 5 genes were induced only in AM. For 21 genes, we could not detect a significant upregulation in any of the symbioses (MtC00474, MtC00486.1, MtC00612, MtC00760, MtC01635, MtC10094, MtC10117, MtC10120, MtC10310, MtC10629, MtC20062, MtC20177, MtC30450, MtC50817, MtC50912, MtC60294, MtC60396, MtC91068, MtC93296, MtD00247, and MtD00968); n.s.i. = not significantly induced in both biological replicates. Rep $=$ Replicate. Unless otherwise noted, MtC cluster identifications, annotations, and the classification into functional categories are based on the current release of the MENS database.

${ }^{\mathrm{b}}$ The gene was identified as being symbiosis-induced by array hybridizations.

${ }^{c}$ The gene was identified as being symbiosis-induced by in silico screening.

${ }^{\mathrm{d}}$ The annotation was updated according to current homologies in the GenBank database. 
noninoculated or inoculated with Sinorhizobium meliloti or G. intraradices, respectively.

The pMtTubbl-gusAint fusion showed GUS activity in the vasculature of noninfected and symbiotic roots. In root nodules, strong GUS staining was visible in all central tissues, including the meristem, the prefixation zone, the interzone, and the infected cells of the nitrogen-fixing zone. Interestingly, no or a very low GUS staining was evident in the noninfected cells. In the outer tissues, weak GUS staining was detected in the inner cortex and the nodule vasculature (Fig. 2C). Con- cerning roots infected with $G$. intraradices, we found strong gus expression in cortical cells containing arbuscules and a weaker staining in the adjacent cells (Fig. 2G). In highly colonized root segments, stronger GUS activity was detectable in the whole cortex, with still more intensely stained arbusculecontaining cells located near the vasculature (Fig. 2F).

The pMtAnn2-gusAint fusion was found to be active during early stages of root nodule induction, where nodule primordia showed strong GUS activity (Fig 2A). In mature nodules, $\mathrm{p} M t A n n 2$ activity was confined to the nodule vasculature,
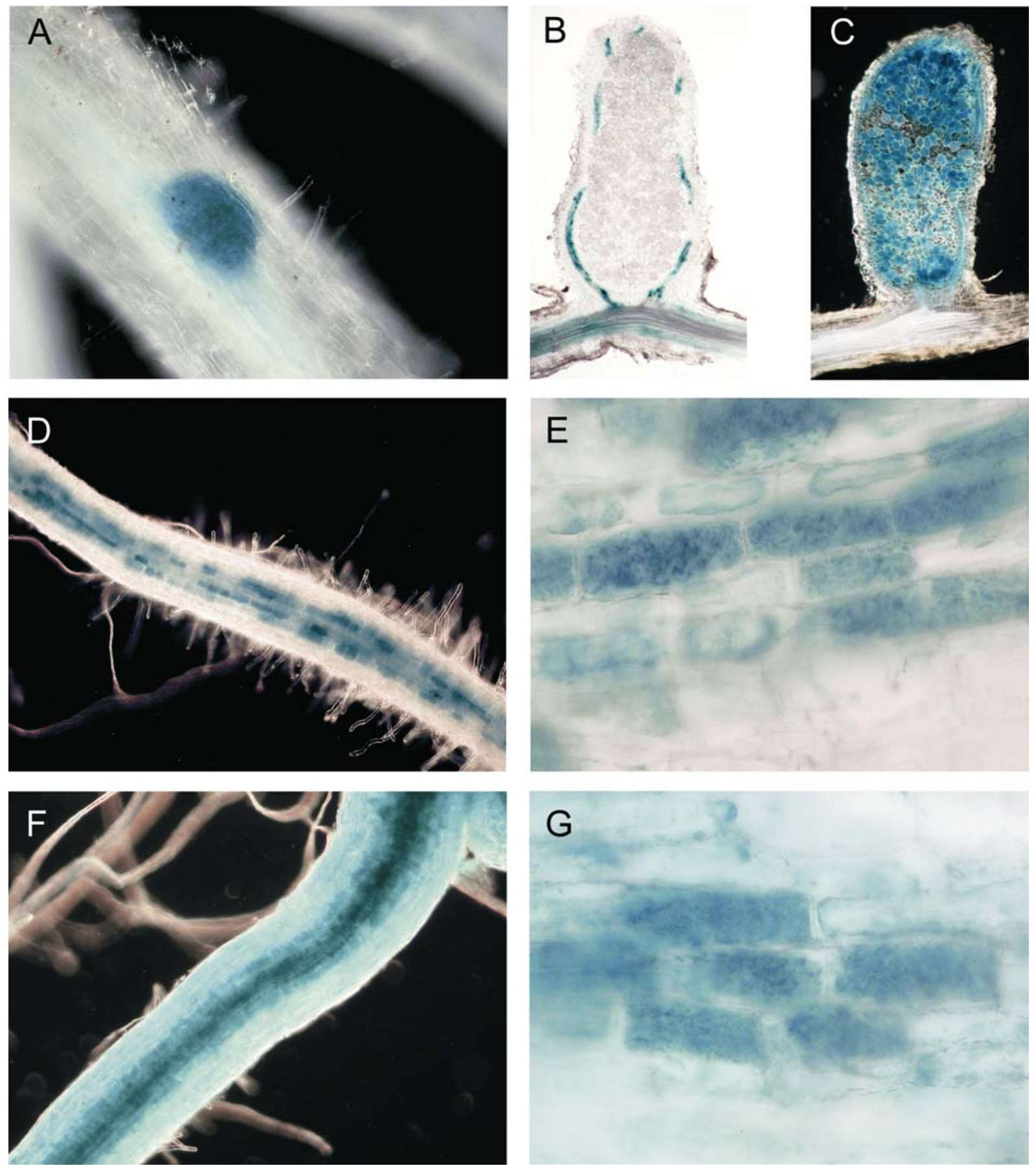

Fig. 2. Activities of an annexin and a $\beta$-tubulin promoter in root nodules and mycorrhizal roots. Histochemical analysis of GUS activity in endosymbiotic tissues transformed with $\mathbf{A}, \mathbf{B}, \mathbf{D}$, and $\mathbf{E}, \mathrm{p} M t A n n 2$-gusAint constructs and $\mathbf{C}, \mathbf{F}$, and $\mathbf{G}$, pMtTubb1-gusAint constructs. A, Nodule primordium showing strong GUS activity. B, Mature root nodule showing MtAnn2 promoter activity restricted to the vasculature. C, Intense MtTubb1 promoter activity is detectable in the central nodule tissues as well as in the inner cortex and the vasculature. D, Segment of a root colonized with Glomus intraradices showing different intensities of GUS staining in arbuscule-containing cells. E, Close-up of arbuscule-containing cells. F, Segment of a mycorrhizal root showing strong GUS activity in the vasculature and in the adjacent arbuscule-containing cells as well as a weaker staining of the whole cortex. G, Close-up of arbuscule-containing cells. 
whereas no gus expression was detectable in any other nodule tissue (Fig. 2B). Occasional and weaker GUS staining was visible in the vasculature of noninfected as well as symbiotic roots. In mycorrhizal roots, strong activity of $\mathrm{p} M t A n n 2$ was confined to arbuscule-containing cells (Fig. 2E). Among those, some displayed a stronger GUS activity than the surrounding cells also containing arbuscules (Fig. 2D), which might reflect a different promoter activity during specific stages of arbuscule development.

\section{DISCUSSION}

\section{Comparing the fidelity}

of experimental and in silico profiling strategies.

An experimental and an in silico expression profiling approach were applied to identify genes induced both during root nodule and AM symbiosis. In both cases, a relatively low stringency was chosen to select a symbiosis-enhanced gene in order to obtain an overlap as large as possible between the two interactions prior to the subsequent verification by real-time RT-PCR.

By array hybridization, we identified a total of 75 candidate genes upregulated during both root nodule and AM symbiosis. Taking into account the high number of genes present on the arrays and the number of genes already found to be induced in both symbioses (e.g., ENOD2 and ENOD40 [van Rhijn et al. 1997] and ENOD11 and ENOD12 [Journet et al. 2001]), one could have expected to identify more symbiosis-enhanced genes. However, cross-hybridization can lead to an underestimation of expression ratios in transcriptional analyses based on arrays, and low-abundance transcripts (e.g., encoding proteins involved in signal transduction) often are below the detection limit of this technique (Colebatch et al. 2002). Another problem probably contributing to the low number of symbiosis-induced genes concerns the detection of genes differentially expressed in AM symbiosis. The presence of noninfected areas in mycorrhizal roots contributes to a dilution of mycorrhiza-specific signals and may interfere with the detection of genes specifically expressed only in mycorrhized regions or arbusculated cells. Such a dilution effect is less pronounced in the nodule symbiosis.

In all, 17 genes found to be symbiosis induced were selected for verification studies by real-time RT-PCR and the symbiosis-enhanced expression could be confirmed for 12 genes. Thus, despite the less stringent significance threshold applied in our array analyses, our results could be validated in most cases. From the 53 candidate genes identified by our in silico screening approach, 18 were confirmed as being symbiosis induced by RT-PCR. Of these, four also were identified by array hybridizations, resulting in the validation of 14 genes that were identified exclusively by in silico profiling. There are several possible explanations for the lower validity of in silico prediction (34\% true positives) compared with experimental expression profiling (70\% true positives). First, we used a much less stringent cutoff value for the likelihood ratio $\mathrm{R}$ as proposed by Journet and associates (2002), thus accepting a lower credibility. However, the finding that we were able to validate the symbiosis-enhanced expression pattern for several genes with a $\mathrm{R}$ value just above 1.5 (for example, MtC10212 and MtC10999) in principal supports this strategy. Furthermore, clusters that were predicted to be upregulated at high $\mathrm{R}$ values are among the clusters that did not show a significant induction in any of the symbioses (for example, MtC10310).

A problem inevitable to in silico analyses is that libraries originating from different conditions are treated as comparable, although differences in the biological material used and the sampling process could be responsible for differences in
EST distribution that only mimic a differential expression. That leads to the identification of genes predicted to be differentially expressed between libraries even though they represent similar conditions (Journet et al. 2002). We tried to overcome the problem using mainly classes composed of several libraries for our comparisons in order to compensate for differences between single libraries. In the case of AM symbiosis, fewer EST data were available compared with the nodule symbiosis. Therefore, we also incorporated the libraries MHAM (Liu et al. 2003) and MtBC (Journet et al. 2002), representing the class mycorrhizae in the comparisons, although both libraries differ in the mycorrhiza fungus used for inoculation as well as in the stage of the biological material harvested. Probably the most important point is that the biological material used for RT-PCR differs from that used for the libraries or library groups screened by the in silico approaches in many aspects (e.g., species of the microsymbiont and the developmental stage of the material). This problem was less pronounced on the array analyses because biological replicates grown under comparable conditions were used for synthesis of hybridization targets and quantitative real-time RT-PCR. Considering these potential biases, the lower number of genes confirmed to be induced in both symbioses on the basis of in silico screening seems reasonable.

\section{Genes specifically activated in only one endosymbiosis.}

Several of the genes found to be induced only in nodules can be connected to important processes of nodule development. The nodule-induced putative ferritin MtC00127 may act as an iron reservoir in nodules, because it was shown that the initially increased protein concentration in nodules decreases up to fivefold concomitantly with the increase in nitrogenase activity and heme protein content (Ragland and Theil 1993). In contrast to the ferritin protein content, the mRNA level remains elevated, probably due to posttranscriptional regulation (Kimata and Theil 1994), which explains the induction measured by RT-PCR.

A gene (MtC45068) with similarities to NRAMPl genes from Lycopersicon esculentum (Bereczky et al. 2003), Oryza sativa (Belouchi et al. 1997), and Arabidopsis thaliana (Curie et al. 2000) also was found to be induced in nodules. NRAMP1 genes encode root-specific metal transporters upregulated by iron starvation. Recently, Kaiser and associates (2003) identified a nodule-enhanced soybean NRAMP homologue probably involved in ferrous iron transport across the peribacteroid membrane, a function that also can be assumed for MtC45068.

Another nodule-induced gene (MtC30105) encodes a putative $\beta$-amylase. These enzymes hydrolyze $\alpha-1,4$-glucosidic polysaccharide linkages from the reducing end. They are inducible by sucrose and other sugars, but also by cold and hormones. Interestingly, their expression may be regulated by sink-source interactions in the whole plant (Mita et al. 1995). However, in roots of forage legumes, $\beta$-amylases are not key enzymes in starch degradation but may function as vegetative storage proteins (Gana et al. 1998). Thus, it is possible that a storage function for amylases might be relevant for root nodules.

The EST cluster MtC00582 is very similar to endo- $\beta-1,4-$ glucanase (EGase) genes from various species, including strawberry (Llop-Tous et al. 1999) and tomato (Catala and Bennett 1998). It shares high homology with Ntcel8, an EGase from tobacco, which is expressed exclusively in giant cells and during syncytia formation in root-nematode interactions (Goellner et al. 2001). Genes that are active both in nematode-induced giant cells or adjacent cells and in nodules have been described (Favery et al. 2002; Koltai et al. 2001). MtC00582 is only weakly similar to MtCel1, a putative EGase from M. truncatula 
found to be induced in AM, where its expression is correlated tightly with arbuscule development (Liu et al. 2003). We found no significant induction of MtC00582 transcripts in mycorrhizal roots, indicating that the gene product does not contribute to cell wall modifications during this symbiosis.

Two genes (MtC93310 and MtC50410.1) induced only in AM encode putative transcription factors that may be responsible for the activation of genes during AM. MtC50410.1 specifies a DELLA protein belonging to the GRAS family of transcription factors (Pysh et al. 1999) and, thus, is a homologue of RGA1 and GAI from A. thaliana (Peng et al. 1997; Truong et al. 1997) that were found to act as negative regulators of the gibberellin (GA) response (Silverstone et al. 1998) and repress GA-related growth effects (Fleck and Harberd 2002). Mycorrhizal roots display increased GA levels without GA-related growth effects (Shaul-Keinan et al. 2002). The higher GA concentrations are thought to increase the strength of the carbohydrate sink in the cells due to the fungal requirements (Blee and Anderson 1998).

\section{Symbiosis-induced genes}

\section{with unknown function or without homology.}

Several symbiosis-induced genes display homologies only to hypothetical proteins. In contrast, MtC00022 is equivalent to NCR122, the only member of the nodule-specific Cys rich (NCR) family expressed in both root nodules and AM according to electronic Northerns (Mergaert et al. 2003). A function for NCR polypeptides as antimicrobial defensins or diffusible signaling molecules was proposed, but the molecular role remains to be elucidated.

Interestingly, a gene that is highly induced in both symbioses (MtC92162) shows no homology to known sequences. A search for open reading frames revealed that there is only a short predicted protein sequence in the $5^{\prime}$-region of the EST cluster. The rare presence of this sequence in $M$. truncatula EST databases is not consistent with the high RNA accumulation found here but this is also the case for MtENOD11 (Journet et al. 2001), which has no corresponding EST despite being strongly induced in nodules and AM.

All other symbiosis-induced genes can be assigned to different functional categories as discussed below.

\section{Symbiosis-induced genes involved in the build-up of cell walls.}

Among the genes induced in both symbioses is the MtN8 gene, which is known to be induced in root nodules. Based on the presence of proline-rich motifs, the encoded protein is structurally related to the early nodulin ENOD2 (Gamas et al. 1996) that was postulated to be a cell wall component (Franssen et al. 1987). ENOD2 was one of the first nodulin genes found to be expressed in both symbioses (van Rhijn et al. 1997). Several other genes encoding repetitive proline-rich proteins currently are known to be induced during both associations: ENOD5 (Albrecht et al. 1998), ENOD12 (Albrecht et al. 1998; Journet et al. 2001), and ENOD11 (Journet et al. 2001). Our finding that MtN8 also is activated in mycorrhizal roots emphasizes the important role of proline-rich proteins in the development of either symbiosis.

\section{Symbiosis-induced genes involved in metabolism and transport.}

Several symbiosis-induced genes identified in this study encode proteins involved in primary metabolism. A gene for the plasma membrane ATPase Mtha1 was strongly upregulated in nodules apart from being activated in AM. Whereas it was previously shown that Mthal transcripts accumulate in arbusculecontaining cells of mycorrhizal tissues (Krajinski et al. 2002), this is the first experimental report of enhanced expression in root nodules as well. This is in accordance with the presence of Mthal ESTs in nodule libraries. Several functions were postulated for Mtha1 in the AM symbiosis: it might be the driving force of transport processes across the periarbuscular membrane or it could be involved in signaling processes in arbuscule-containing cells (Krajinski et al. 2002). An interesting question is whether the protein has a similar function in the infected cells of root nodules in connection to the peribacteroid membrane.

A further gene induced in both symbioses is the early nodulin gene ENOD8. The ENOD8 protein belongs to the GDSL family of lipolytic enzymes and, to date, at least three different ENOD8 genes are known in M. truncatula (Dickstein et al. 2002). The EST sequence used for our analysis corresponds to the ENOD8.1 gene, which is specifically and strongly expressed in nodules (Dickstein et al. 2002). This is in accordance to the high upregulation in nodules found here. Although electronic Northerns suggest that ENOD8 might be induced at a low level in roots infected with the fungus Phytophthora medicaginis (Dickstein et al. 2002), our results are the first evidence for an induction by AM fungi. Recent studies revealed that the ENOD8 protein might associate with the symbiosome membrane in root nodules (Catalano et al. 2004) and it is tempting to speculate that it is likewise associated to the periarbuscular membrane in AM. Nevertheless, the function of ENOD8 in both symbioses remains to be determined.

Two genes encoding nodulin 26-like proteins were found to be upregulated to different degrees in both symbioses. Nodulin 26 is a major protein component in the symbiosome membrane of root nodules (Miao and Verma 1993), where it forms an aquaporin channel and confers high water permeability (Dean et al. 1999; Rivers et al. 1997). It is subject to phosphorylation by calcium-dependent protein kinases that increases water permeability. This phosphorylation is regulated in response to osmotic signals; therefore, it was postulated that nodulin 26 has a role in an osmoregulation of the symbiosome membrane (Dean et al. 1999; Guenther et al. 2003; Rivers et al. 1997). A protein cross-reacting with nodulin 26 also was detected in arbuscular mycorrhizal roots (Wyss et al. 1990) and recent studies by Brechenmacher and associates (2004) revealed the AM induction of a gene coding for a nodulin 26like protein that is equivalent to $\mathrm{MtC} 10430$. Thus, nodulin 26like genes also might be involved in osmoregulation in the AM symbiosis, where the inner volume of arbusculated cells is largely occupied by fungal structures.

\section{Symbiosis-induced genes}

with similarities to defense- and stress-related genes.

A significant proportion of the symbiosis-induced genes are involved in defense and stress responses as reported by Liu and associates (2003) for early stages of the AM symbiosis. In general, defense responses in the AM are thought to be weak and transient, although few defense-related genes are also expressed in later stages (Garcia-Garrido and Ocampo 2002; Harrison 1999). In the case of the root nodules, elicitation of defense mechanisms by rhizobia also has been described (Santos et al. 2001; Vasse et al. 1993) but, likewise, a suppression of these mechanisms was observed in later stages of the symbiosis (Mithöfer 2002; Sikorski et al. 1999).

The symbiosis-induced defense-related protein specified by EST cluster MtC60183 is similar to an abscisic acid-responsive pathogenesis-related protein (PR10) from chickpea (Cervantes et al. 1995) and pea (Iturriaga et al. 1994). It is weakly similar to the nodule-induced MtN13 gene, which also belongs to the PR10 family (Gamas et al. 1998). PR10 proteins were annotated as ribonuclease-like proteins (Bantignies 
et al. 2000). In pea, a PR10 gene was found to be induced in $\mathrm{AM}$ and also transiently in Rhizobium spp.-inoculated roots (Ruiz-Lozano et al. 1999); whereas, in Lotus japonicus, a PR10 protein was identified as a component of the peribacteroid membrane (Wienkoop and Saalbach 2003). On the other hand, MtC60183 also is related to MtPR10-1, a gene that shows a root-enhanced expression in M. truncatula (Gamas et al. 1998). Moreover, the expression of two PRIO genes is significantly decreased in young and mature nodules of lupin (Sikorski et al. 1999). This might reflect the observation that there are nodule-induced and root-enhanced genes among alternative members of multigene families (Journet et al. 2002).

Other defense-related genes are MtD00868, with homologies to a gene coding for a pathogenesis-related, fungus-induced protein from barley (Jutidamrongphan et al. 1989), and MtC93362, which is weakly similar to an elicitor-responsive and wound-induced gene from Nicotiana tabacum (Takemoto et al. 2003) and potato (Logemann and Schell 1989), respectively. A different wound-induced protein from $M$. truncatula recently was shown to be induced in mycorrhizal roots (Brechenmacher et al. 2004). In addition, MtC10662 is similar to a dehydration stress-induced protein from Brassica napus (AAK01359) and an elicitor-inducible protein from $N$. tabacum (Takemoto et al. 2001)

The symbiosis-induced gene encoding a putative lipase (MtC50550) is weakly similar to an ethylene-induced lipase gene from carnation flowers (Dianthus caryophyllus) expressed at the onset of petal senescence (Hong et al. 2000). Although the ethylene production in mycorrhizal roots is elevated (Dugassa et al. 1996), it is unclear whether or not the $M$. truncatula lipase is regulated by ethylene.

Finally, a symbiosis-induced gene represented by EST cluster MtC10348.1 is weakly similar to genes encoding glyoxalase I-like proteins. These glutathione-dependent enzymes are upregulated in plants by environmental stress and during cell division (Dixon et al. 1998). The upregulation of a member of the glutathione-mediated detoxification system in AM symbiosis would be consistent with the observed induction of a glutathione-S-transferase in mycorrhized regions of roots colonized by $G$. intraradices (Wulf et al. 2003).

\section{Symbiosis-induced genes involved in protein processing, signal transduction, and gene expression.}

Two genes (MtC60261 and MtC91471) found to be strongly induced in both symbioses encode cysteine proteinases. The induction of the gene represented by EST cluster MtC60261 in both symbioses was described recently (Liu et al. 2003). The encoded proteins of both genes are highly homologous to nodule-specific cysteine proteinases from Chinese milk vetch (Naito et al. 2000) and the actinorhizal plant Alnus glutinosa (Goetting-Minesky and Mullin 1994) and share weak homologies with two nodule-specific cysteine proteinases from M. truncatula (Fedorova et al. 2002). MtC60261 and MtC91471 are weakly similar to a cysteine proteinase gene with increased expression in senescent nodules of soybean (Alesandrini et al. 2003). The EST clusters encoding both cysteine proteinases contain only ESTs from nodule and AM libraries, thus confirming that they represent a group of symbiosis-specific cysteine proteinases. Naito and associates (2000) suggest that the nodule-specific cysteine proteinase may be involved in the recycling of nitrogen compounds from senescing bacteroids. Thus, the observed common induction of a cysteine proteinase in both symbioses points toward common steps in nodule and arbuscule senescense (Liu et al. 2003). Our results show that, in $M$. truncatula, there is at least a second cysteine proteinase involved in these processes. Interestingly, two additional cysteine pro- teinases were found to be symbiosis-induced on the basis of our array data (Table 1).

Also related to protein processing, a symbiosis-induced gene (MtD01860) is weakly similar to a component of the E3 ubiquitin ligase from Arabidopsis thaliana being involved in a specific pathway of protein degradation (Potuschak et al. 1998; Stary et al. 2003). The similarity is most pronounced to the two RING finger domains of the A. thaliana protein and it remains to be clarified if the $M$. truncatula gene also is involved in ubiquitinylation processes.

To date, several transcription factors, such as MADS boxcontaining genes, NDX homeobox genes, homeodomain, and zinc finger proteins, are known to be involved in nodulation (Crespi and Galvez 2000; Gronlund et al. 2003), but almost nothing is known about transcription factors driving the expression of genes in AM. One gene found to be symbiosis induced in our study encodes the TATA box-binding protein (TBP) of the basal transcription factor TFIID. In eukaryotes, initiation of transcription by RNA polymerase II requires the sequence-specific binding of the TFIID complex, including the TBP to the promoter. TBP, together with different TBP-associated factors, forms distinct TFIID complexes that may have specific roles in transcriptional regulation (Bell and Tora 1999). The increased amount of TBP in symbiotic tissues compared with control roots may reflect the higher transcriptional activity in these tissues. In addition, two zinc finger proteins were found to be induced in root nodules and AM. The putative transcriptional adaptor zinc (TAZ) finger containing protein (MtC00467) may be responsible for the specific activation of genes expressed in both associations. The second protein (MtC10823) contains a CCCH-type zinc finger domain and an ankyrin repeat that is a common protein-protein interaction motif. It might likewise play a role in the symbiosisspecific initiation of transcription.

\section{Spatial expression pattern}

of the two symbiosis-induced genes MtTubb1 and MtAnn2.

In this study, transcriptomics tools were used for the identification of genes that might be relevant for root nodule and AM symbioses. However, our data were obtained from RNA samples representing whole organs that, although they were harvested at a particular time point, nonetheless contained different symbiotic stages, because the colonization of the microsymbiont and the development of the symbiosis is asynchronous. Hence, information on the localization of gene expression in specific cells, tissues, and stages could not be obtained from global transcriptome profiling. Thus, we determined the spatial expression of two symbiosis-induced genes in noninfected and symbiotic roots to better characterize their role in symbiosis development.

MtTubbl encodes a $\beta$-tubulin, which, apart from $\alpha$-tubulin, is the major component of microtubules. Transgenic mycorrhizal roots expressing the pMtTubbl-gusAint construct showed strongest GUS staining in cortical cells containing arbuscules and a weaker staining in the adjacent cells. This points to a predominant induction of pMtTubb1 in the infected cells of AM roots. The induction of a $\beta$-tubulin gene in mycorrhizal roots is in accordance with the identification of the AM-inducible $\alpha$-tubulin gene Tub $\alpha 3$ in maize (Bonfante et al. 1996), but the expression patterns of both genes are slightly different. The Tub $\alpha 3$ promoter was found to be activated in the root tips but not in the vasculature, and GUS staining in mycorrhized regions was restricted to infected cells. On the protein level, higher amounts of $\alpha-, \beta$-, and $\gamma$-tubulin were observed in mycorrhizal tomato roots compared with noncolonized roots (Timonen and Peterson 2002). The increased tubulin synthesis results from the rearrangement of microtubules in cortical cells 
colonized by AM fungi that was first shown by Genre and Bonfante (1997). Recent studies revealed that reorganization also occurs in noninfected cells adjacent to arbuscules or intercellular hyphae (Blancaflor et al. 2001), which is with the MtTubbl expression pattern observed in this study.

Concerning root nodules, pMtTubbl activity was observed in all central tissues as well as in the inner cortex and the vasculature. This is in accordance with microtubular cytoskeleton changes occurring in the root nodule central tissues during infection thread growth, bacterial release, cell enlargement in the prefixation zone, and the positioning of bacteroids and organelles in the infected cells (Timmers et al. 1998).

The symbiosis-induced annexin MtAnn2 is a paralogue of the Nod factor-induced annexin MtAnn1 (de Carvalho-Niebel et al. 1998), which shows enhanced transcript levels in Rhizobium spp.-inoculated roots and nodules. MtAnnl transcripts were found to be associated with the distal part of the invasion zone by in situ hybridization (de Carvalho-Niebel et al. 1998), whereas no transcripts were detected in peripheral nodule tissues. In contrast, activation of the MtAnn2 promoter in nodules was confined to the vasculature, with no gus expression being detectable in the central tissues. Concerning early stages of the nodule symbiosis, MtAnnl was found to be expressed simultaneously in both inner and outer root tissues during both preinfection and infection (de Carvalho-Niebel et al. 2002). In addition, high levels of MtAnnl transcripts were detected in all cells of the nodule primordium (de Carvalho-Niebel et al. 1998). MtAnn2 also is expressed strongly in the nodule primordium; therefore, both annexin genes, to some extent, exhibit a similar activation pattern in this early stage of the symbiosis.

Interestingly, electronic Northern data and experimental expression studies available for MtAnnl do not indicate an induction during AM symbiosis, whereas we were able to show that MtAnn2 is activated specifically in arbuscule-containing cells. Intriguingly, these two annexin genes with markedly different and at least, to some extent, complementary expression patterns are located in tandem in the $M$. truncatula genome (BAC Mth2-145p10; GenBank accession AC146590), presumably originating from a gene duplication event. Members of the annexin family were reported to be involved in various processes, including cytoskeleton rearrangements, the regulation of membrane organization and membrane traffic, and the regulation of ion currents across membranes (Gerke and Moss 2002) For MtAnn1, a role in cell cycle reactivation or cytoskeleton rearrangements during early stages of nodulation was postulated (de Carvalho-Niebel et al. 2002). A function for MtAnn2 in cytoskeleton rearrangements would be compatible with its induction in cells containing arbuscules, although this reorganization is not restricted to these cells (Blancaflor et al. 2001). The invading fungus is surrounded by a novel membrane of plant origin; therefore, a role of MtAnn2 in connection with membrane traffic in arbuscule-containing cells also can be assumed.

\section{Conclusion and perspectives.}

Transcription profiling based on array hybridization and in silico screening approaches identified a collection of novel genes upregulated in both the root nodule and AM symbiosis. These genes are connected to several processes relevant for endosymbioses, such as membrane transport, primary metabolism, defense and stress responses, and the regulation of gene expression. In connection with the cellular expression localization of two symbiosis-induced genes, our results provide a valuable data set for future functional studies targeted at determining the function of the encoded gene products during the root symbiotic program of $M$. truncatula.

\section{MATERIALS AND METHODS}

\section{Biological material.}

For the production of either sterile or symbiotic root material, $M$. truncatula cv. Jemalong A17 plants were used. Roots colonized by $G$. intraradices and nonmycorrhized control roots were obtained as described by Wulf and associates (2003). Mycorrhizal roots were harvested 3 weeks after inoculation with Granular AMF inoculum (G. intraradices, EB3/01/58; BIORIZE, Dijon, France). Using our experimental conditions, at this time point the mycorrhization frequency reached $100 \%$, and the degree of mycorrhization and the arbuscule frequency was 77 to $83 \%$ (parameters calculated according to Trouvelot et al. 1986). For the induction of nodules, $M$. truncatula seed were surface sterilized and germinated as described by Wulf and associates (2003). The seedlings were transferred into pots with vermiculite/perlite (1:1) and were grown in a growth chamber with a photoperiod of $16 \mathrm{~h}$ at $22^{\circ} \mathrm{C}$ and a dark phase of $8 \mathrm{~h}$ at $18^{\circ} \mathrm{C}$. Plants ( 1 to 2 weeks old) were inoculated with Sinorhizobium meliloti 2011 (Meade and Signer 1977). The noninoculated plants were fertilized weekly with a half-strength Hoagland's solution (Arnon and Hoagland $1940)$, whereas a reduced nitrate concentration $(3.75 \mathrm{mM})$ was used in case of the inoculated plants. Roots from 6-week-old noninoculated control plants and mature nodules (4 weeks postinoculation) were harvested and immediately frozen in liquid nitrogen.

\section{RNA extraction.}

Total RNA from mycorrhized and nonmycorrhized control roots was extracted using the $\mathrm{LiCl}$ method (Franken and Gnädinger 1994) whereas total RNA from root nodules and control roots was isolated using TRI Reagent (Sigma-Aldrich Chemie GmbH, Steinheim, Germany) according to the provided protocol. RNA preparations were checked on agarose gels, quantified photometrically, and stored at $-80^{\circ} \mathrm{C}$.

\section{Hybridization of Mt6k-RIT macroarrays.}

The hybridization of Mt6k-RIT macroarrays, including the synthesis of ${ }^{33} \mathrm{P}$-labeled cDNA targets, hybridization conditions, and image acquisitions, was performed as described by Küster and associates (2004). Spot detection and quantification of signals were performed using the ImaGene software (version 5.0; BioDiscovery Inc., Los Angeles). During image processing, no automatic flagging for "empty" spots was done. The resulting data files were imported into the EMMA $1.0 \mathrm{mi}-$ croarray analysis software (Dondrup et al. 2003). Data from two consecutive hybridizations on the same membrane with targets from roots nodules and AM, respectively, and the corresponding control tissues were treated like one microarray hybridization experiment. We performed two technical replicates for each tissue, resulting in two experiments for each symbiosis that were combined for further analysis.

All spots were used for calculation of $\mathrm{M}$ values $\left(\log _{2}\right.$ of expression ratios) and A values ( $\log _{2}$ of average signal intensities) and data normalization was done based on a local regression (lowess) procedure. To identify genes that were significantly upor downregulated, a $t$ statistic was applied according to Dudoit and associates (2002). Genes were regarded as being differentially expressed if $P \leq 0.075$ and $\mathrm{M} \geq 0.7$ or $\leq-0.7$. Normalization and $t$ statistics were implemented in the EMMA 1.0 software (Dondrup et al. 2003). Subsequently, the resulting gene list was checked for the presence of empty control spots that were not removed automatically during the analysis due to the absence of a flagging step. All spots with an A value below a threshold value for A that was defined according to the A value of these empty spots were removed manually. 
Hybridization of Mt6k-RIT microarrays.

The synthesis of reverse-transcribed Cy-labeled cDNA targets was performed as described by Küster and associates (2004). To obtain Cy-labeled cDNA targets amplified by PCR, first-strand cDNA was synthesized from $1 \mu \mathrm{g}$ of total RNA using the SMART PCR cDNA synthesis Kit (BD Biosciences Clontech, Palo Alto, CA, U.S.A.). A PCR amplification in a total volume of $50 \mu \mathrm{l}$ using $2 \mu \mathrm{l}$ of first-strand cDNA, $2 \mu \mathrm{l}$ of SMART cDNA primers $(10 \mu \mathrm{M}$; SMART PCR cDNA synthesis Kit; BD Biosciences Clontech), $0.7 \mu \mathrm{l}$ of $50 \times$ dNTP solution $(25 \mathrm{mM}$ dATP, $25 \mathrm{mM}$ dCTP, $25 \mathrm{mM}$ dGTP, $8.3 \mathrm{mM}$ dTTP, $16.7 \mathrm{mM}$ aminoallyl-dUTP), and $1 \mu \mathrm{l}$ of Advantage 2 Polymerase Mix (Advantage 2 PCR Kit; BD Biosciences Clontech) was performed to incorporate amino-allyl-dUTP into the PCR products. The following PCR program was used: initial denaturation at $95^{\circ} \mathrm{C}$ for $1 \mathrm{~min} ; 35$ cycles of PCR at $94^{\circ} \mathrm{C}$ for $15 \mathrm{~s}, 65^{\circ} \mathrm{C}$ for $30 \mathrm{~s}$, and $68^{\circ} \mathrm{C}$ for $6 \mathrm{~min}$; and terminal extension at $68^{\circ} \mathrm{C}$ for 6 min. Subsequently, Cy3 and Cy 5 NHS esters were coupled to the amino-allyl-labeled first-strand cDNA using reactive dye packs according to the manufacturer's instructions (Amersham Biosciences, Freiburg, Germany). Hybridization of Mt6k-RIT microarrays with Cy-labeled cDNA targets and the subsequent image acquisition and analysis were carried out as described by Küster and associates (2004), except that the lowess normalization was not performed within print tip groups and the threshold values for differentially regulated genes were set to $P \leq 0.075$ and $\mathrm{M} \leq-0.7$ or $\geq 0.7$.

\section{Electronic Northerns.}

For the prediction of genes with symbiosis-enhanced expression, an in silico screening tool available online was used. The following comparisons were analyzed with a threshold value for $\mathrm{R}$ of 1.5: library $\mathrm{MtBC} /$ metaclass roots, library MHAM/metaclass roots, class mycorrhizae/metaclass roots, class mature nodules/metaclass roots, class young nodules/metaclass roots, and class Rhizobium roots/metaclass roots. The libraries, classes, and metaclasses, as well as the likelihood ratio $\mathrm{R}$ are described in the MENS database and by Journet and associates (2002). EST clusters that were predicted to be upregulated at $\mathrm{R} \geq 1.5$ in MtBC, MHAM, or mycorrhizae and simultaneously in mature nodules, young nodules, or Rhizobium roots were considered for further analysis.

\section{Quantitative real-time RT-PCR.}

Quantitative real-time RT-PCR was carried out as described by Hohnjec and associates (2003). In short, the Quantitect SYBR Green RT-PCR kit (Qiagen, Hilden, Germany) was used for one-step RT-PCR with the Opticon real-time PCR cycler (MJ Research, Waltham, MA, U.S.A.). Specificity of amplification products was checked by performing a heat dissociation protocol after the final PCR step and a subsequent agarose gel electrophoresis. Primers had a calculated melting temperature between 51 and $55^{\circ} \mathrm{C}, \mathrm{PCR}$ products were 150 to 330 bp in size, and primer sequences were unique in the TIGR $M$. truncatula Gene Index and the MENS database.

\section{Construction}

of MtTubb1 and MtAnn2 promoter-gus Aint fusions.

A 1,727-bp MtTubbl promoter fragment $(-1,756$ to -29 in relation to the ATG) was PCR amplified from BAC sequence Mth2-10e12 (GenBank accession AC137078) and a 1,742-bp MtAnn2 promoter fragment $(-1,768$ to -26 in relation to the ATG) was isolated using BAC sequence Mth2-145p10 (GenBank accession AC146590) as a PCR template. Both promoter fragments were fused to the gusAint gene of plasmid pGUSINT (Küster et al. 1995) using terminal restriction sites introduced during PCR (NcoI/HindIII in the case of pMtTubbl and
XhoI/HindIII in the case of $\mathrm{pMtAnn2)}$. The chimeric promotergusAint constructs were inserted as Klenow-blunted NcoI/XbaI (pMtTubb1) and StuI/XbaI (pMtAnn2) fragments, respectively, into the SmaI site of the binary vector pRedRoot (Limpens et al. 2004).

\section{Agrobacterium rhizogenes-mediated root transformation of M. truncatula and histochemical analysis of transgenic tissues.}

Agrobacterium rhizogenes strain Arqual (Quandt et al. 1993) was transformed with binary plasmids and used to induce transgenic hairy roots according to a protocol by Vieweg and associates (2004). After cutting off the wild-type root, the majority of the plants was inoculated either with $S$. meliloti 2011 (Meade and Signer 1977) or G. intraradices (Granular AMF inoculum, $G$. intraradices, BB-E/SC-02; BIORIZE), whereas some plants were retained as noninfected controls. Histochemical assays for GUS activity were performed on symbiotic roots 4 to 5 weeks after inoculation and on noninfected roots of a comparable age as described by Vieweg and associates (2004). Prior to the GUS assay, transgenic hairy roots were identified by detecting dsRed fluorescence using a Leica MZ FLIII fluorescence stereomicroscope, and semi-thin sections $(80 \mu \mathrm{m})$ of root nodules were prepared using a Leica VT100S microtome (Leica, Wetzlar, Germany). GUS staining was examined by light microscopy using an Olympus BH-2 and documented using an Olympus C-2000Z digital camera (Olympus, Hamburg, Germany). GUS-stained mycorrhizal roots were counterstained with black ink as described by Vierheilig and associates (1998) to verify the presence of fungal structures.

\section{ACKNOWLEDGMENTS}

This work was supported by the Deutsche Forschungsgemeinschaft SPP 1084 "Mykorrhiza" as well as the European Union project MEDICAGO (QLG2-CT-2000-00676). N. Hohnjec and H. Küster acknowledge financial support by the Bielefeld University International NRW Graduate School in Bioinformatics and Genome Research. René Geurts (Wageningen University, Laboratory of Molecular Biology) is acknowledged for supplying the pRedRoot plasmid prior to publication. We are grateful to A. Becker (Institute of Genome Research, Bielefeld University) for supporting array hybridization experiments, to M. Dondrup (BRF, Center for Biotechnology, Bielefeld University) for his help in using the EMMA database, and to M. Vieweg for his support in photographic documentation.

\section{LITERATURE CITED}

Albrecht, C., Geurts, R., Lapeyrie, F., and Bisseling, T. 1998. Endomycorrhizae and rhizobial Nod factors both require SYM8 to induce the expression of the early nodulin genes PsENOD5 and PsENOD12A. Plant J. 15:605-614.

Alesandrini, F., Mathis, R., Van de Sype, G., Herouart, D., and Puppo, A. 2003. Possible roles for a cysteine protease and hydrogen peroxide in soybean nodule development and senescence. New Phytol. 158:131138.

Ané, J. M., Kiss, G. B., Riely, B. K., Penmetsa, R. V., Oldroyd, G. E. D., Ayax, C., Levy, J., Debelle, F., Baek, J. M., Kalo, P., Rosenberg, C., Roe, B. A., Long, S. R., Denarie, J., and Cook, D. R. 2004. Medicago truncatula DMI1 required for bacterial and fungal symbioses in legumes. Science 303:1364-1367

Arnon, D. I., and Hoagland, D. R. 1940. Crop production in artificial solutions and soils with special reference to factors influencing yield and absorption of inorganic nutrients. Soil Sci. 50:463-471.

Augé, R. M. 2001. Water relations, drought and VA mycorrhizal symbiosis. Mycorrhiza 11:3-42.

Bantignies, B., Seguin, J., Muzac, I., Dedaldechamp, F., Gulick, P., and Ibrahim, R. 2000. Direct evidence for ribonucleolytic activity of a PR10-like protein from white lupin roots. Plant Mol. Biol. 42:871-881.

Barker, D. G., Bianchi, S., Blondon, F., Dattée, Y., Duc, G., Essad, S., Flament, P., Gallusci, P., Génier, G., Guy, P., Muel, X., Tourneur, J., Dénarié, J., and Huguet, T. 1990. Medicago truncatula, a model plant 
for studying the molecular genetics of the Rhizobium-legume symbiosis. Plant Mol. Biol. Rep. 8:40-49.

Bell, B., and Tora, L. 1999. Regulation of gene expression by multiple forms of TFIID and other novel TAF(II)-containing complexes. Exp. Cell. Res. 246:11-19.

Belouchi, A., Kwan, T., and Gros, P. 1997. Cloning and characterization of the OsNramp family from Oryza sativa, a new family of membrane proteins possibly implicated in the transport of metal ions. Plant Mol. Biol. 33:1085-1092.

Bereczky, Z., Wang, H. Y., Schubert, V., Ganal, M., and Bauer, P. 2003. Differential regulation of nramp and irt metal transporter genes in wild type and iron uptake mutants of tomato. J. Biol. Chem. 278:2469724704.

Blancaflor, E. B., Zhao, L., and Harrison, M. J. 2001. Microtubule organization in root cells of Medicago truncatula during development of an arbuscular mycorrhizal symbiosis with Glomus versiforme. Protoplasma 217:154-165.

Blee, K. A., and Anderson, A. J. 1998. Regulation of arbuscule formation by carbon in the plant. Plant J. 16:523-530.

Bonfante, P., Berbero, R., Uribe, X., Romera, C., Rigau, J., and Puigdomenech, P. 1996. Transcriptional activation of a maize alphatubulin gene in mycorrhizal maize and transgenic tobacco plants. Plant J. 9:737-743.

Bradbury, S. M., Peterson, R. L., and Bowley, S. R. 1991. Interactions between three alfalfa nodulation genotypes and two Glomus species. New Phytol. 119:115-120.

Brechenmacher, L., Weidmann, S., van Tuinen, D., Chatagnier, O. Gianinazzi, S., Franken, P., and Gianinazzi-Pearson, V. 2004. Expression profiling of up-regulated plant and fungal genes in early and late stages of Medicago truncatula/Glomus mosseae interactions. Mycorrhiza 10.1007/s00572-003-0263-4. Online publication.

Brewin, N. J. 1991. Development of the legume root nodule. Annu. Rev. Cell Biol. 7:191-226.

Catala C., and Bennett A. B. 1998. Cloning and sequence analysis of Tomcel8; a new plant endo-beta-1,4-D-glucanase gene, encoding a protein with a putative carbohydrate binding domain (accession no. AF098292) (PGR98-209) Plant Physiol. 118:1535.

Catalano, C. M., Lane, W. S., and Sherrier, D. J. 2004. Biochemical characterization of symbiosome membrane proteins from Medicago truncatula root nodules. Electrophoresis 25:519-531.

Cervantes, E., Nicolas, C., Gonzalez, B., and Iturriaga, E. A. 1995. Isolation and expression characteristics of CaPR-10a, an IPR coding cDNA from chickpea seeds. (PGR95-115). Plant Physiol. 110:335.

Coba de la Pena, T., Frugier, F., McKhann, H. I., Bauer, P., Brown, S., Kondorosi, A., and Crespi, M. 1997. A carbonic anhydrase gene is induced in the nodule primordium and its cell-specific expression is controlled by the presence of Rhizobium during development. Plant J. 11:407-420.

Colebatch, G., Kloska, S., Trevaskis, B., Freund, S., Altmann, T., and Udvardi, M. K. 2002. Novel aspects of symbiotic nitrogen fixation uncovered by transcript profiling with cDNA arrays. Mol. Plant-Microbe Interact. 15:411-420.

Cordier, C., Gianinazzi, S., and Gianinazzi-Pearson, V. 1996. Colonisation patterns of root tissues by Phytophthora nicotianae var. parasitica related to reduced disease in mycorrhizal tomato. Plant Soil 185:223-232.

Crespi, M., and Galvez, S. 2000. Molecular mechanisms in root nodule development. J. Plant Growth Regul. 19:155-166.

Curie, C., Alonso, J. M., Le Jean M., Ecker, J. R., and Briat, J. F. 2000. Involvement of NRAMP1 from Arabidopsis thaliana in iron transport. Biochem. J. 347:749-755.

Dean, R. M., Rivers, R. L., Zeidel, M. L., and Roberts, D. M. 1999. Purification and functional reconstitution of soybean nodulin 26: An aquaporin with water and glycerol transport properties. Biochemistry 38:347-353

de Carvalho-Niebel F., Lescure, N., Cullimore, J. V., and Gamas, P. 1998. The Medicago truncatula MtAnn1 gene encoding an annexin is induced by nod factors and during the symbiotic interaction with Rhizobium meliloti. Mol. Plant-Microbe Interact. 11:504-513.

de Carvalho-Niebel, F., Timmers, A. C., Chabaud, M., Defaux-Petras, A., and Barker, D. G. 2002. The Nod factor-elicited annexin MtAnn1 is preferentially localised at the nuclear periphery in symbiotically activated root tissues of Medicago truncatula. Plant J. 32:343-352.

Dickstein, R., Hu, X. J., Yang, J., Ba, L., Coque, L., Kim, D. J., Cook, D. R., and Yeung, A. T. 2002. Differential expression of tandemly duplicated Enod8 genes in Medicago. Plant Sci. 163:333-343.

Dixon, D. P., Cummins, I., Cole, D. J., and Edwards, R. 1998 Glutathione-mediated detoxification systems in plants. Curr. Opin. Plant Biol. 1:258-266.

Dondrup, M., Goesmann, A., Bartels, D., Kalinowski, J., Krause, L., Linke, B., Rupp, O., Pühler, A., and Meyer, F. 2003. EMMA: a platform for consistent storage and efficient analysis of microarray data. J. Biotechnol. 106:135-146.

Duc, G., Trouvelot, A. , Gianinazzi-Pearson, V., and Gianinazzi, S. 1989. First report of non-mycorrhizal plant mutants (Myc-) obtained in pea (Pisum sativum L.) and fababean (Vicia faba L.). Plant Sci. 60:215-222.

Dudoit, S., Yang, Y. H., Callow, M. J., and Speed T. P. 2002. Statistica methods for identifying differentially expressed genes in replicated cDNA microarray experiments. Stat. Sin. 12:111-139.

Dugassa, G. D., von Alten, H., and Schönbeck, F. 1996. Effects of arbuscular mycorrhiza (AM) on health of Linum usitatissimum L. infected by fungal pathogens. Plant Soil. 185:173-182.

Endo, M., Matsubara, H., Kokubun, T., Masuko, H., Takahata, Y., Tsuchiya, T., Fukuda, H., Demura, T., and Watanabe M. 2002. The advantages of cDNA microarray as an effective tool for identification of reproductive organ-specific genes in a model legume, Lotus japonicus. FEBS (Fed. Eur. Biol. Soc.) Lett. 514:229-237.

Endre, G., Kereszt, A., Kevei, Z., Mihacea, S., Kalo, P., and Kiss, G. B. 2002. A receptor kinase gene regulating symbiotic nodule development. Nature 417:962-966.

Favery, B., Complainville, A., Vinardell, J. M., Lecomte, P., Vaubert, D., Mergaert, P., Kondorosi, A., Kondorosi, E., Crespi, M., and Abad, P 2002. The endosymbiosis-induced genes ENOD40 and CCS52a are involved in endoparasitic-nematode interactions in Medicago truncatula. Mol. Plant-Microbe Interact. 15:1008-1013.

Fedorova, M., van de Mortel, J., Matsumoto, P. A., Cho, J., Town, C. D., VandenBosch, K. A., Gantt, J. S., and Vance, C. P. 2002. Genome-wide identification of nodule-specific transcripts in the model legume Medicago truncatula. Plant Physiol. 130:519-537.

Fleck, B., and Harberd, N. P. 2002. Evidence that the Arabidopsis nuclear gibberellin signalling protein GAI is not destabilised by gibberellin. Plant J. 32:935-947.

Franken, P., and Gnädinger, F. 1994. Analysis of parsley arbuscular endomycorrhiza: infection development and mRNA levels of defense-related genes. Mol. Plant-Microbe Interact. 7:612-620.

Franssen, H. J., Nap, J. P., Gloudemans, T., Stiekema, W., Van Dam, H., Govers, F., Louwerse, J., Van Kammen, A., and Bisseling, T. 1987. Characterization of cDNA for nodulin-75 of soybean: a gene product involved in the early stages of root nodule development. Proc. Natl. Acad. Sci. U.S.A. 84:4495-4499.

Frühling, M., Roussel, H., Gianinazzi-Pearson, V., Pühler, A., and Perlick, A. M. 1997. The Vicia faba leghemoglobin gene VfLb29 is induced in root nodules and in roots colonized by the arbuscular mycorrhizal fungus Glomus fasciculatum. Mol. Plant-Microbe Interact. 10:124-131.

Gamas, P., de Billy, F., and Truchet, G. 1998. Symbiosis-specific expression of two Medicago truncatula nodulin genes, MtN1 and MtN13, encoding products homologous to plant defense proteins. Mol. PlantMicrobe Interact. 11:393-403.

Gamas, P., de Carvalho-Niebel, F., Lescure, N., and Cullimore, J. 1996. Use of a subtractive hybridization approach to identify new Medicago truncatula genes induced during root nodule development. Mol. PlantMicrobe Interact. 9:233-242.

Gana, J. A., Kalengamaliro, N. E., Cunningham, S. M., and Volenec, J. J. 1998. Expression of beta-amylase from alfalfa taproots. Plant Physiol. 118:1495-1506.

Garcia-Garrido, J. M., and Ocampo, J. A. 2002. Regulation of the plant defence response in arbuscular mycorrhizal symbiosis. J. Exp. Bot. 53:1377-1386

Genre, A., and Bonfante, P. 1997. A mycorrhizal fungus changes microtubule orientation in tobacco root cells. Protoplasma 199:30-38.

Gerke, V., and Moss, S. E. 2002. Annexins: From structure to function. Physiol. Rev. 82:331-371.

Goellner, M., Wang, X., and Davis, E. L. 2001. Endo-beta-1,4-glucanase expression in compatible plant-nematode interactions. Plant Cell 13:2241-2255.

Goetting-Minesky, M. P., and Mullin, B. C. 1994. Differential gene expression in an actinorhizal symbiosis: evidence for a nodule-specific cysteine proteinase. Proc. Natl. Acad. Sci. U.S.A. 91:9891-9895.

Gronlund, M., Gustafsen, C., Roussis, A., Jensen, D., Nielsen, L. P., Marcker, K. A., and Jensen, E. O. 2003. The Lotus japonicus ndx gene family is involved in nodule function and maintenance. Plant Mol. Biol. 52:303-316.

Guenther, J. F., Chanmanivone, N., Galetovic, M. P., Wallace, I. S., Cobb, J. A., and Roberts, D. M. 2003. Phosphorylation of soybean nodulin 26 on serine 262 enhances water permeability and is regulated developmentally and by osmotic signals. Plant Cell 15:981-991.

Handberg, K., and Stougaard, J. 1992. Lotus japonicus, an autogamous, diploid legume species for classical and molecular genetics. Plant J. 2:487-496.

Harrison, M. J. 1999. Molecular and cellular aspects of the arbuscular mycorrhizal symbiosis. Ann. Rev. Plant Physiol. Plant Mol. Biol. 50:361-389. 
Harrison, M. J., Dewbre, G. R., and Liu, J. 2002. A phosphate transporter from Medicago truncatula involved in the acquisition of phosphate released by arbuscular mycorrhizal fungi. Plant Cell 14:2413-2429.

Hohnjec, N., Perlick, A. M., Pühler, A., and Küster, H. 2003. The Medicago truncatula sucrose synthase gene MtSucS1 is activated both in the infected region of root nodules and in the cortex of roots colonized by arbuscular mycorrhizal fungi. Mol. Plant-Microbe Interact. 16:903-915.

Hong, Y. W., Wang, T. W., Hudak, K. A., Schade, F., Froese, C. D., and Thompson, J. E. 2000. An ethylene-induced cDNA encoding a lipase expressed at the onset of senescence. Proc. Natl. Acad. Sci. U.S.A. 97:8717-8722.

Iturriaga, E. A., Leech, M. J., Barratt, D. H., and Wang, T. L. 1994. Two ABA-responsive proteins from pea (Pisum sativum L.) are closely related to intracellular pathogenesis-related proteins. Plant Mol. Biol. 24:235-240.

Journet, E. P., El-Gachtouli, N., Vernoud, V., de Billy, F., Pichon, M. Dedieu, A., Arnould, C., Morandi, D., Barker, D. G., and GianinazziPearson, V. 2001. Medicago truncatula ENOD11: A novel RPRP-encoding early nodulin gene expressed during mycorrhization in arbuscule-containing cells. Mol. Plant-Microbe Interact. 14:737-748.

Journet, E. P., van Tuinen, D., Gouzy, J., Crespeau, H., Carreau, V., Farmer, M. J., Niebel, A., Schiex, T., Jaillon, O., Chatagnier, O., Godiard, L., Micheli, F., Kahn, D., Gianinazzi-Pearson, V., and Gamas, P. 2002. Exploring the root symbiotic programs of the model legume Medicago truncatula using EST analysis. Nucleic Acids Res. 30:55795592.

Jutidamrongphan, W., Mackinnon, G., Manners, J. M., and Scott, K. J. 1989. Sequence of a near-full length cDNA clone for a mRNA of barley induced by fungal infection. Nucleic Acids Res. 17:9478.

Kaiser, B. N., Moreau, S., Castelli, J., Thomson, R., Lambert, A., Bogliolo, S., Puppo, A., and Day, D. A. 2003. The soybean NRAMP homologue, GmDMT1, is a symbiotic divalent metal transporter capable of ferrous iron transport. Plant J. 35:295-304.

Kimata, Y., and Theil, E. C. 1994. Posttranscriptional regulation of ferritin during nodule development in soybean. Plant Physiol. 104:263-270.

Koltai, H., Dhandaydham, M., Opperman, C., Thomas, J., and Bird, D. 2001. Overlapping plant signal transduction pathways induced by a parasitic nematode and a rhizobial endosymbiont. Mol. Plant-Microbe Interact. 14:1168-1177.

Krajinski, F., Hause, B., Gianinazzi-Pearson, V., and Franken, P. 2002. Mtha1, a plasma membrane $\mathrm{H}^{+}$-ATPase gene from Medicago truncatula, shows arbuscule-induced expression. Plant Biol. 4:754-761.

Küster, H., Schröder, G. Frühling, M., Pich, U., Rieping, M., Schubert, I., Perlick, A. M., and Pühler, A. 1995. The nodule-specific VfENODGRP3 gene encoding a glycine-rich early nodulin is located on chromosome I of Vicia faba L. and is predominiantly expressed in the interzone II-III of root nodules. Plant Mol. Giol. 28:405-421.

Küster, H., Hohnjec, N., Krajinski, F., El Yahyaoui, F., Manthey, K., Gouzy, J., Dondrup, M., Meyer, F., Kalinowski, J., Brechenmacher, L., van Tuinen, D., Gianinazzi-Pearson, V., Pühler, A., Gamas, P., and Becker, A. 2004. Construction and validation of cDNA-based Mt6kRIT macro- and microarrays to explore root endosymbioses in the model legume Medicago truncatula. J. Biotechnol. 108:95-113.

Lamblin, A. F., Crow, J. A., Johnson, J. E., Silverstein, K. A., Kunau, T. M., Kilian, A., Benz, D., Stromvik, M., Endre, G., VandenBosch, K. A., Cook, D. R., Young, N. D., and Retzel, E. F. 2003. MtDB: a database for personalized data mining of the model legume Medicago truncatula transcriptome. Nucleic Acids Res. 31:196-201.

Levy, J., Bres, C., Geurts, R., Chalhoub, B., Kulikova, O., Duc, G., Journet, E. P., Ané, J. M., Lauber, E., Bisseling, T., Denarie, J., Rosenberg, C. and Debelle, F. 2004. A putative $\mathrm{Ca}^{2+}$ and calmodulin-dependent protein kinase required for bacterial and fungal symbioses. Science 303:1361-1364

Limpens, E., Ramos, J., Franken, C., Raz, V., Compaan, B., Franssen, H., Bisseling, T., and Geurts, R. 2004. RNA interference in Agrobacterium rhizogenes-transformed roots of Arabidopsis and Medicago truncatula. J. Exp. Bot. 55:983-992.

Liu, J., Blaylock, L. A., Endre, G., Cho, J., Town, C. D., VandenBosch, K. A., and Harrison, M. J. 2003. Transcript profiling coupled with spatial expression analyses reveals genes involved in distinct developmental stages of an arbuscular mycorrhizal symbiosis. Plant Cell. 15:2106-2123.

Llop-Tous, I., Dominguez-Puigjaner, E., Palomer, X., and Vendrell, M. 1999. Characterization of two divergent endo-beta-1,4-glucanase cDNA clones highly expressed in the nonclimacteric strawberry fruit. Plant Physiol. 119:1415-1422.

Logemann, J., and Schell, J. 1989. Nucleotide sequence and regulated expression of a wound-inducible potato gene (wun1). Mol. Gen. Genet. 219:81-88.

Maguire, T. L., Grimmond, S., Forrest, A., Iturbe-Ormaetxe, I., Meksem, K., and Gresshoff, P. M. 2002. cDNA microarray analysis of soybean
(Glycine max): tissue-specific gene expression. J. Plant Physiol. 159:1361-1374.

Meade, H. M., and Signer, E. R. 1977. Genetic mapping of Rhizobium meliloti. Proc. Natl. Acad. Sci. U.S.A. 74:2076-2078.

Mergaert, P., Nikovics, K., Kelemen, Z., Maunoury, N., Vaubert, D., Kondorosi, A., and Kondorosi, E. 2003. A novel family in Medicago truncatula consisting of more than 300 nodule-specific genes coding for small, secreted polypeptides with conserved cysteine motifs. Plant Physiol. 132:161-173.

Miao, G. H., and Verma, D. P. 1993. Soybean nodulin-26 gene encoding a channel protein is expressed only in the infected cells of nodules and is regulated differently in roots of homologous and heterologous plants. Plant Cell 5:781-794.

Mita, S., Suzuki-Fujii, K., and Nakamura K. 1995. Sugar-inducible expression of a gene for beta-amylase in Arabidopsis thaliana. Plant Physiol. 107:895-904.

Mithöfer, A. 2002. Suppression of plant defence in rhizobia-legume symbiosis. Trends Plant Sci. 7:446-450.

Naito, Y., Fujie, M., Usami, S., Murooka, Y., and Yamada, T. 2000. The involvement of a cysteine proteinase in the nodule development in Chinese milk vetch infected with Mesohizobium huakuii subsp. rengei. Plant Physiol. 124:1087-1095.

Newsham, K. K., Fitter, A. H., and Watkinson, A. R. 1995. Arbuscular mycorrhiza protect an annual grass from root pathogenic fungi in the field. J. Ecol. 83:991-1000.

Pathirana, S. M., Vance, C. P., Miller, S. S., and Gantt, J. S. 1992. Alfalfa root nodule phosphoenolpyruvate carboxylase: characterization of the cDNA and expression in effective and plant-controlled ineffective nodules. Plant Mol Biol. 20:437-450.

Peng, J., Carol, P., Richards, D. E., King, K. E., Cowling, R. J., Murphy, G. P., and Harberd N. P. 1997. The Arabidopsis GAI gene defines a signaling pathway that negatively regulates gibberellin responses. Genes Dev. 11:3194-3205.

Potuschak, T., Stary, S., Schlogelhofer, P., Becker, F., Nejinskaia, V., and Bachmair, A. 1998. PRT1 of Arabidopsis thaliana encodes a component of the plant N-end rule pathway. Proc. Natl. Acad. Sci. U.S.A. 95:7904-7908.

Pysh, L. D., Wysocka-Diller, J. W., Camilleri, C., Bouchez, D., and Benfey, P. N. 1999. The GRAS gene family in Arabidopsis: sequence characterization and basic expression analysis of the SCARECROW-LIKE genes. Plant J. 18:111-119.

Quackenbush, J., Cho, J., Lee, D., Liang, F., Holt, I., Karamycheva, S., Parvici, B., Pertea, G., Sultana, R., and White, J., 2000. The TIGR Gene Indices: analysis of gene transcript sequences in highly sampled eukaryotic species. Nucleic Acids Res. 29:159-164.

Quandt, H. J., Pühler, A., and Broer, I. 1993. Transgenic root nodules of Vicia hirsuta. A fast and efficient system for the study of gene expression in indeterminate-type nodules. Mol. Plant-Microbe Interact. 6:699-703.

Ragland, M., and Theil, E. C. 1993. Ferritin (mRNA, protein) and iron concentrations during soybean nodule development. Plant Mol Biol. 21:555-560.

Rivers, R. L., Dean, R. M., Chandy, G., Hall, J. E., Roberts, D. M., and Zeidel M. L. 1997. Functional analysis of nodulin 26, an aquaporin in soybean root nodule symbiosomes. J. Biol. Chem. 272:16256-16261.

Ruiz-Lozano, J. M., Roussel, H., Gianinazzi, S., and Gianinazzi-Pearson, V. 1999. Defense genes are differentially induced by a mycorrhizal fungus and Rhizobium sp in wild-type and symbiosis-defective pea genotypes. Mol. Plant-Microbe Interact. 12:976-984.

Santos, R., Herouart, D., Sigaud, S., Touati, D., and Puppo, A. 2001. Oxidative burst in alfalfa-Sinorhizobium meliloti symbiotic interaction Mol. Plant-Microbe Interact. 14:86-89.

Schüssler, A., Schwarzott, D., and Walker, C., 2001. A new fungal phylum, the Glomeromycota: phylogeny and evolution. Mycol. Res. 105:1413-1421.

Shaul-Keinan, O., Gadkar, V., Ginzberg, I., Grunzweig, J. M., Chet, I., Elad, Y., Wininger, S., Belausov, E., Eshed, Y., Arzmon, N., Ben-Tal, Y., and Kapulnik, Y. 2002. Hormone concentrations in tobacco roots change during arbuscular mycorrhizal colonization with Glomus intraradices. New Phytol. 154:501-507.

Sikorski, M. M., Biesiadka, J., Kasperska, A. E., Kopcinska, J., Lotocka, B., Golinowski, W., and Legocki, A. B. 1999. Expression of genes encoding PR10 class pathogenesis-related proteins is inhibited in yellow lupine root nodules. Plant Sci. 149:125-137.

Silverstone, A. L., Ciampaglio, C. N., and Sun, T. 1998. The Arabidopsis RGA gene encodes a transcriptional regulator repressing the gibberellin signal transduction pathway. Plant Cell 10:155-169.

Slezack, S., Dumas-Gaudot, E., Paynot, M., and Gianinazzi, S. 2000. Is a fully established arbuscular mycorrhizal symbiosis required for a bioprotection of Pisum sativum roots against Aphanomyces euteiches? Mol. Plant-Microbe Interact. 13:238-241. 
Stary, S., Yin, X. J., Potuschak, T., Schlogelhofer, P., Nizhynska, V., and Bachmair, A. 2003. PRT1 of Arabidopsis is a ubiquitin protein ligase of the plant $\mathrm{N}$-end rule pathway with specificity for aromatic amino-terminal residues. Plant Physiol. 133:1360-1366.

Strack, D., Fester, T., Hause, B., Schliemann, W., and Walter, M. H. 2003. Arbuscular mycorrhiza: biological, chemical, and molecular aspects. J. Chem. Ecol. 29:1955-1979.

Stracke, S., Kistner, C., Yoshida, S., Mulder, L., Sato, S., Kaneko, T., Tabata, S., Sandal, N., Stougaard, J., Szczyglowski, K., and Parniske, M. 2002. A plant receptor-like kinase required for both bacterial and fungal symbiosis. Nature 417:959-962.

Subramanian, K. S., Charest C., Dwyer L. M., and Hamilton R. I. 1995. Arbuscular mycorrhizae and water relations in maize under drought stress at tasselling. New Phytol. 129:643-650.

Takemoto, D., Doke, N., and Kawakita, K. 2001. Characterization of elicitor-inducible tobacco genes isolated by differential hybridization. J. Gen. Plant Pathol. 67:89-96.

Takemoto, D., Yoshioka, H., Doke, N., and Kawakita, K. 2003. Disease stress-inducible genes of tobacco: expression profile of elicitor-responsive genes isolated by subtractive hybridization. Physiol. Plant. 118:545-553.

Timmers, A. C. J., Auriac, M. C., de Billy, F., and Truchet, G. 1998. Nod factor internalization and microtubular cytoskeleton changes occur concomitantly during nodule differentiation in alfalfa. Development 125:339-349.

Timonen, S., and Peterson, R. L. 2002. Cytoskeleton in mycorrhizal symbiosis. Plant Soil. 244: 199-210.

Trouvelot, A., Kough, J. L., and Gianinazzi-Pearson, V. 1986. Mesure du taux de mycorhization VA d'un système radiculaire. Recherche des méthodes d'estimation ayant une signification fonctionnelle. Pages 217-221 in: The Mycorrhizae: Physiology and Genetics. V. GianinazziPearson and S. Gianinazzi, eds. INRA Presse, Paris.

Truong, H. N., Caboche, M., and Daniel-Vedele, F. 1997. Sequence and characterization of two Arabidopsis thaliana cDNAs isolated by functional complementation of a yeast gln 3 gdh1 mutant. FEBS (Fed. Eur. Biol. Soc.) Lett. 410:213-218.

Uhde-Stone, C., Zinn, K. E., Ramirez-Yanez, M., Li, A., Vance, C. P., and Allan, D. L. 2003. Nylon filter arrays reveal differential gene expression in proteoid roots of white lupin in response to phosphorus deficiency. Plant Physiol. 131:1064-1079.
VandenBosch K. A., and Stacey G. 2003. Summaries of legume genomics projects from around the globe. Community resources for crops and models. Plant Physiol. 131:840-865

Van Rhijn, P., Fang, Y., Galili, S., Shaul, O., Atzmon, N., Wininger, S., Eshed, Y., Lum, M., Li, Y., To, V., Fujishige, N., Kapulnik, Y., and Hirsch, A. M. 1997. Expression of early nodulin genes in alfalfa mycorrhizae indicates that signal transduction pathways used in forming arbuscular mycorrhizae and Rhizobium-induced nodules may be conserved. Proc. Natl. Acad. Sci. U.S.A. 94:5467-5472.

Vasse J, de Billy F, and Truchet G. 1993. Abortion of infection during the Rhizobium meliloti-alfalfa symbiotic interaction is accompanied by a hypersensitive reaction. Plant J. 4:555-566.

Vierheilig, H., Coughlan, A. P., Wyss, U., and Piche, Y. 1998. Ink and vinegar, a simple staining technique for arbuscular-mycorrhizal fungi. Appl. Environ. Microbiol. 64:5004-5007.

Vieweg, M. F., Frühling, M., Quandt, H. J., Heim, U., Bäumlein, H., Pühler, A., Küster, H., and Perlick, A. M. 2004. The promoter of the Vicia faba L. leghemoglobin gene VfLb29 is specifically activated in the infected cells of root nodules and in the arbuscule-containing cells of mycorrhizal roots from different legume and nonlegume plants. Mol. Plant-Microbe Interact. 17:62-69.

Wienkoop S., and Saalbach, G. 2003. Proteome analysis. Novel proteins identified at the peribacteroid membrane from Lotus japonicus root nodules. Plant Physiol. 131:1080-1090.

Wulf, A., Manthey, K., Doll, J., Perlick, A. M., Linke, B., Bekel, T. Meyer, F., Franken, P., Küster, H., and Krajinski, K. 2003. Transcriptional changes in response to arbuscular mycorrhiza development in the model plant Medicago truncatula. Mol. Plant-Microbe Interact. 16:306314.

Wyss, P., Mellor, R. B., and Wiemken, A. 1990. Vesicular-arbuscular mycorrhizas of wild-type soybean and non-nodulating mutants with Glomus mosseae contain symbiosis-specific polypeptides (mycorrhizins), immunologically cross-reactive with nodulins. Planta 182:2226

\section{AUTHOR-RECOMMENDED INTERNET RESOURCE}

INRA, Medicago EST navigation system (MENS), in silico screening tool: medicago.toulouse.inra.fr/Mt/EST/DOC/MtB.html 